\title{
Demokratisasi Dan Desentralisasi Partai Demokrasi Indonesia Perjuangan Dalam Pemilukada Provinsi Sumatera Utara Tahun 2018
}

\section{Democratization and Decentralization of Indonesian Democratic Party of Struggle in the General Election of Regional Heads of North Sumatra Province in 2018}

\author{
Junedi Lumban Gaol, Muryanto Amin \& Heri Kusmanto* \\ Program Studi Magister Ilmu Politik, Fakultas Ilmu Sosial Dan Ilmu Politik, \\ Universitas Sumatera Utara, Indonesia \\ Diterima: 04 Agustus 2021; Direview: 04 Agustus 2021; Disetujui: 29 Desember 2021
}

\begin{abstract}
Abstrak
Tujuan dari penelitian ini adalah untuk menganalisis dan menjelaskan eksistensi demokrasi internal partai dan desentralisasi kewenangan partai di PDI Perjuangan melalui pemilihan Djarot-Sihar dan dasar pertimbangan PDI Perjuangan mengusung kader dewan pengurus pusat sebagai pasangan calon kepala daerah pada perhelatan Pemilukada provinsi Sumatera Utara tahun 2018. Penelitian ini merupakan penelitian kualitatif dengan analisa deskriptif. Penelitian ini dimaksudkan untuk menggambarkan dan menjelaskan secara mendalam tingkat demokrasi dan desentralisasi kekuasaan dan kewenangan partai politik dalam pengambilan keputusan, khususnya dalam pencalonan, penetapan sampai pada tahap pengajuan Kandidat Gubernur dan Wakil Gubernur pada Pemilukada Sumatera Utara Periode 2018-2023. PDI Perjuangan menerapkan bentuk demokrasi internal partai dengan pola yang terpimpin dimana Ketua Umum memiliki kewenangan istimewa dalam menentukan bentuk dan prosedur tata laksana demokrasi internal itu sendiri yang dijamin oleh Piagam Partai, Anggaran Dasar Partai, dan Anggaran Rumah Tangga Partai; Rekrutmen calon kepala daerah dan atau wakil kepala daerah tidak diselenggarakan secara demokratis sesuai dengan prinsip demokrasi liberal, dimana pengambilan keputusan dalam pencalonan kandidat berada pada Ketua Umum Partai. Penetapan Djarot-Sihar sebagai pasangan calon gubernur dan wakil gubernur Provinsi Sumatara Utara pada Pemilukada tahun 2018 didasarkan pada pertimbangan strategis partai sesuai dengan kalkulasi politik Ketua Umum dan jajaran elite partai.

Kata Kunci: Demokratisasi; Desentralisasi; Partai Demokrasi Indonesia Perjuangan; Pemilukada
\end{abstract}

\section{Abstrak}

The purpose of this study is to analyze and explain the existence of internal party democracy and the decentralization of party authority in the PDI-P through the Djarot-Sihar election and the basis for consideration of PDI-P carrying out the cadres of the central board of directors as a candidate pair for regional heads at the 2018 North Sumatra Provincial Election. qualitative research with descriptive analysis. This study is intended to describe and explain in depth the level of democracy and decentralization of power and authority of political parties in decision-making, especially in the nomination, determination up to the stage of submitting the Candidates for Governor and Deputy Governor in the General Election of Regional Heads of North Sumatra for the 2018-2023 Period. PDI-P implements a form of internal party democracy with a guided pattern where the General Chair has special authority in determining the form and procedure for administering internal democracy itself which is guaranteed by the Party Charter, Party Articles of Association, and Party Bylaws; The recruitment of candidates for regional heads and/or deputy regional heads is not carried out democratically in accordance with the principles of liberal democracy, where the decision making in the nomination of candidates rests with the General Chairperson of the Party. The determination of Djarot-Sihar as a candidate pair for governor and deputy governor of North Sumatra Province in the 2018 Regional Head General Election was based on party strategic considerations in accordance with the political calculations of the General Chair and party elite ranks. Keywords: Democratization; Decentralization; Indonesian Democratic Party of Struggle; General Election

How to Cite: Lumban Gaol, J., Amin, M., \& Kusmanto, H. (2022). Demokratisasi Dan Desentralisasi Partai Demokrasi Indonesia Perjuangan Dalam Pemilukada Provinsi Sumatera Utara Tahun 2018. PERSPEKTIF, 11 (1): 333-354. 


\section{PENDAHULUAN}

Partai politik dan demokrasi adalah dua perangkat politik yang saling tergantung dan saling mempengaruhi satu sama lainnya. Demokrasi tanpa eksistensi partai politik merupakan suatu kemustahilan, dan sebaliknya partai politik tanpa demokrasi adalah suatu kesiasiaan. Schattschneider (1942) mengklaim bahwa partai politik telah membentuk demokrasi moderen dimana demokrasi itu sendiri tidak akan dapat diwujudkan tanpa peranan partai politik (political parties have created modern democracy and democracy is inconceivable without political parties).

Pewujudan demokrasi dalam aspekaspek kehidupan masyarakat dalam hubungannya dengan Negara hanya dapat diselenggarakan melalui peran partai politik melalui berfungsinya sebagai aggregator aspirasi dan kepentingan warga negara. Seluruh lapisan masyarakat mulai dari tingkat terbawah hingga teratas (golongan elit) berkumpul dan berjuang bersama dalam mewujudkan cita-cita dan hak-hak politiknya melalui partai politik. Peran sentral partai politik dalam demokrasi dapat dilihat dalam pandangan Scarrow (2005) yang menyatakan bahwa partai politik merupakan aktor terpenting di dalam sistem demokrasi perwakilan. Partai dapat membantu kelompokkelompok masyarakat dalam menyampaikan keinginannya kepada pemerintah, membentuk kepemimpinan politik, mempersiapkan dan mengajukan alternatif kebijakan publik, dan menghadirkan alternatif pilihan yang koheren kepada para pemilih (masyarakat) dalam Pemilihan Umum. Lebih tajam, Sartori (1997) menyatakan bahwa peran fundamental partai politik adalah untuk mewujudkan keterhubungan warga negara dengan negara (pemerintah).

Peranan dan fungsi partai tersebut dapat berbentuk penyediaan pilihan-pilihan elektoral dalam bentuk janji politik sebagai formulasi awal kebijakan publik dan pemilihan serta pengajuan kandidat pejabat publik yang ditawarkan dalam pemilihan umum. Partai politik menjadi penentu bagaimana dan siapa calon kandidat yang dipilih dan dipromosikan serta isu politik apa yang dikemas sebagai janji politik dalam pemilihan umum yang nantinya menjadi substansi kebijakan publik. Partai politik menjadi satu-satunya opsi yang harus dipilih oleh masyarakat apabila ia ingin mengambil bagian dalam proses penyelenggaraan Negara dalam pemerintahan demokratis.

Para ilmuwan politik klasik seperti Duverger (1964), Michels (1915), Panebianco (1988), dan Weber (2004) juga menyatakan bahwa partai politik memiliki peran yang sangat dominan dan menonjol di dalam sistem demokrasi. Keberhasilan atau kegagalan demokrasi dalam memajukan masyarakat menjadi tanggung jawab mutlak partai politik. Namun di dalam prakteknya, partai politik sering menjadi faktor penghambat berlangsungnya demokrasi baik dalam perspektif prosedural maupun substansial. Hal ini sebagai akibat dari dominannya fungsi, peranan, dan tugas yang melekat pada partai politik itu sendiri. Untuk menjamin keberlangsungan seluruh fungsi, peran, dan tugas tersebut, partai politik memerlukan stabilitas yang mapan. Pengambilan setiap kebijakan dan atau keputusan strategis partai cenderung tertutup yang mengarah pada oligarki elite partai sebagai langkah awal untuk mengantisipasi terjadinya perpecahanperpecahan dalam tubuh partai politik itu sendiri. Alih-alih menjalankan proses demokrasi, partai terkesan bertindak otoriter dalam penentuan setiap kebijakan strategis partai. Partai seolah dipersonalisasikan dengan Ketua Umum Partai. Tahapan-tahapan demokratis dalam dinamika pengambilan keputusan di dalam partai seolah menjadi sesuatu yang harus dihindari.

Fenomena oligarki partai ini juga terjadi dalam berbagai proses politik di Indonesia. Dalam Pemilihan Umum Kepala Daerah (Pemilukada) misalnya, penentuan kandidat yang diajukan/ diusung/didukung oleh suatu partai politik dalam perheletan suatu pemilukada selalu diputuskan oleh dewan pimpinan tertinggi setiap partai di Indonesia. Dewan pimpinan di daerah dan atau wilayah tidak memiliki kewenangan penuh dalam menentukan kandidat yang akan bertarung dalam suatu pemilukada di suatu daerah. Keputusan penentuan kandidat tersentralisasi dengan sangat kuat dan ketat pada Dewan Pimpinan Pusat. Desentralisasi kewenangan penentuan kandidat oleh dewan peiminan pusat kepada dewan pimpinan daerah sebagai salah satu perwujudan modernisasi dan demokratisasi partai politik tidak berjalan 
dengan baik. Sebaliknya pengambilan keputusan diambil dengan prinsip top down policy (sentralistik) yang terkadang tanpa memandang aspirasi anggota partai, simpatisan, pendukung, dan dewan peimpinan daerah partai tersebut (Ramadani et al., 2017; Wicaksono, 2021; Putra et al., 2021).

Menilik realitas politik yang berlangsung di lapangan, kita dapat melihat bahwa dewan kepengurusan partai pada tingkat daerah tidak memiliki otoritas mutlak untuk memilih dan menetapkan calon kepala daerah yang akan bertarung dalam kancah pemilukada, baik pemilihan gubernur maupun pemilihan bupati/wali kota. Keputusan penetapan calon kepala daerah diambil oleh dewan kepengurusan pusat, dan keputusan yang sudah diambil oleh pusat bersifat final dan mengikat. Dewan kepengurusan partai di tingkat daerah wajib untuk mengikuti dan menyukseskan kebijakan yang sudah ditentukan oleh dewan kepengurusan pusat (Nurdin, 2021; Nurazizah., \& Dewi, 2021; Suharyanto, 2017).

Dalam hal perbaikan tata kelola partai politik di Indonesia, Fariz (2018), salah satu anggota Indonesia Corruption Watch (ICW) menilai, perkembangan partai politik masih berjalan di tempat selama era reformasi. Fariz berpandangan bahwa sejak era reformasi di Indonesia, perbaikan di berbagai lembagalembaga pemerintahan termasuk sistem pemilihan umum sudah dilaksanakan, namun reformasi di dalam tubuh partai politik belum dijalankan. "Modernisasi pemilu berjalan baik, tapi kita lupa bagaimana memastikan partai politik baik secara organisasi dan tata kelola", (Fariz, 2018).

Mencermati realitas politik yang sedang berlangsung di Indonesia saat ini, tampak jelas bahwa oligarki sebagaimana yang dinyatakan Winters (2011) merupakan hambatan sekaligus tantangan bagi partai-partai politik di Indonesia secara keseluruhan. Hampir seluruh partai peserta pemilu dikuasai dan dikendalikan oleh elite-elite politik yang telah memiliki sosial kapital yang sangat besar serta tokoh-tokoh nasional yang sudah memiliki reputasi tinggi dan nama besar di kancah perpolitikan nasional.

Seluruh kebijakan dan keputusan politik partai ditentukan oleh elite melalui mekanisme hierarki kekuasaan yang sangat kaku (rigid) dan cenderung bernuansa komando/perintah (petunjuk atau arahan ketua umum). Ketua umum beserta golongan elite partai di lingkaran terdekatnya merupakan sosok-sosok penentu dalam pengambilan setiap keputusan strategis partai (party decision making), terutama dalam penentuan calon Kepala Daerah maupun calon wakilnya yang akan mengikuti perhelatan Pemilukada.

Menjadi tidak mengherankan tatkala pemilihan kepala daerah sedang bergulir di suatu daerah (provinsi atau kabupaten/kota), partai politik cenderung memprioritaskan tokoh yang dinilai memiliki sosial kapital yang besar dan atau figur yang sudah memiliki nama besar dan reputasi yang tinggi untuk dicalonkan. Bahkan kerap terjadi, figur kandidat yang dicalonkan suatu partai politik berasal dari luar partai politik meskipun calon tersebut tidak memiliki basis pendukung di dalam partai politik tersebut. Disamping figur non partai, partai politik juga sering mengusung kader partai yang keanggotaannya tidak berada di daerah penyelenggara Pemilukada.

Sebagai contoh, proses pencalanan Jarot S. Hidayat dan Dr. Sihar PH. Sitorus sebagai calon gubernur dan calon wakil gubernur sumatera utara pada pemilihan gubernur sumatera utara tahun 2018, sebagaimana yang diutarakan oleh ketua umum partai demokrasi indonesia perjuangan (PDI. Perjuangan), Megawati Soekarno Putri (https://nasional.kompas.com/read/2018/01 /04/21201911/cerita-megawati-di-balikterpilihnya-djarot-jadi-calon-gubernur-sumut. Artikel ini tayang di Kompas.com dengan judul "Cerita Megawati di Balik Terpilihnya Djarot Jadi Calon Gubernur Sumut", Kompas.com04/01/2018, 21:20 WIB): "Jadi saya bilang, tiba-tiba ketika saya sudah pusing, saya tidak sreg, lalu tiba-tiba lagi pergi dengan Sekjen PDIP. Saya lihat tampangnya Hasto (Kristiyanto), kenapa tidak cari di dekat kita si Djarot. "Kasihan masih muda disuruh nganggur".

Lebih jauh, Megawati menjelaskan; "Saya bilang saya ketua umum partai memerintahkan petugas partai, kamu mau enggak masuk Sumut. 'Siap Bu, sebagai petugas partai saya bersedia' begitu kata Pak Djarot.Untuk itulah saya sedang mempertimbangkan, memikirkan dengan mendalam, sekiranya Bapak Djarot Syaiful Hidayat, saya tetapkan dulu sebagai bakal calon gubernur untuk Sumatera Utara". 
Menguatnya oligarki dan sentraliasasi kekuasaaan/ kewenangan di dalam tubuh partai politik seperti yang tergambar dalam proses kandidasi calon kepala daerah oleh PDI Perjuangan dalam Pemilukada serentak pada tahun 2018 silam merupakan ancaman serius terhadap eksistensi demokrasi baik dalam tatanan suprastruktur politik maupun infrastruktur politik. Apabila kondisi ini tidak segera perbaiki, maka fenomena deparpolisasi yang sudah mulai menggejala di tengah masyarakat akan bermetamorfosa menjadi sikap antipati atau bahkan apatisme masyarakat terhadap politik maupun partai politik.

Adapun tujuan dari penelitian ini adalah sebagai berikut: Menganalisis dan menjelaskan eksistensi demokrasi internal partai dan desentralisasi kewenangan partai di PDI Perjuangan melalui pemilihan Djarot-Sihar sebagai calon gubernur dan wakil gubernur pada Pemilukada Sumatera Utara tahun 2018; Menganalisis dan menjelaskan dasar pertimbangan PDI Perjuangan mengusung kader dewan pengurus pusat sebagai pasangan calon kepala daerah pada perhelatan Pemilukada provinsi Sumatera Utara tahun 2018.

\section{METODE PENELITIAN}

Penelitian ini merupakan penelitian kualitatif dengan analisa deskriptif. Penelitian ini dimaksudkan untuk menggambarkan dan menjelaskan secara mendalam tingkat demokrasi dan desentralisasi kekuasaan dan kewenangan partai politik dalam pengambilan keputusan, khususnya dalam pencalonan, penetapan sampai pada tahap pengajuan Kandidat Gubernur dan Wakil Gubernur pada Pemilukada Sumatera Utara Periode 20182023.

Subjek/informan dalam penelitian ini adalah sebagai berikut: Drs. Jarot Syaiful Hidayat sebagai Calon Kepala Daerah yang diusung oleh PDIP pada Pemilihan Gubernur Sumatera Utara Periode 2018-2023; Dewan Pimpinan Daerah PDIP Sumatera Utara (Ketua dan Sekretaris/ dan Drs. Jarot Syaiful Hidayat dan Drs Sutarto, M.Si ); Wakil Sekretaris DPD PDIP Sumatera Utara (Ahmad Bima Nusa, M.Si).

Pengumpulan data dalam penelitian ini dilakukan dengan berbagai tindakan yakni melakukan interviu mendalam terhadap informan kunci (key informan) dan informan tambahan, mengumpulkan dokumen partai terkait dengan syarat dan sistem (mekanisme) pencalonan kandidat Kepala dan Wakil Kepala Daerah, mengumpulkan data dan informasi terkait kandidasi PID Perjuangan yang ada di media cetak serta mencatat semua data dan informasi lainnya yang dirasa perlu untuk menjawab masalah penelitian sebagaiamana yang telah dirumuskan.

Teknik analisis yang digunakan dalam penelitian ini adalah analisis interaktif sebagaimana yang dikemukakan oleh Miles dan Huberman dalam Sugiyono (2011) yaitu proses analisis yang dilakukan bersamaan dengan proses pengumpulan data. Dalam menyelesaikan penelitian ini, penulis melakukan interpretasi dan konseptualisasi terhadap setiap data yang telah ditemukan dalam penelitian sejak awal hingga akhir penelitian dalam rangka membangun konsepsi analitik yang utuh dalam memecahkan dan menjelaskan masalah penelitian yang sudah dirumuskan di awal.

\section{HASIL DAN PEMBAHASAN \\ Konsep Demokrasi Internal PDI Perjuangan dan Eksistensinya Dalam Pemilihan Kandidat Gubernur dan Wakil Gubernur}

Dalam menganilsis konsepsi demokrasi internal PDI Perjuangan dan eksistensi dalam pememilihan kandidat gubernur dan wakil gubernur dalam perhelatan Pemilukada Provinsi Sumtara Utara tahun 2018, penulis mengadopsi pandagan Rahat and Hazan (2010) yang mengemukakan bahwa pemilihan kandidat suatu partai diselenggarakan secara demokratis apabila partai tersebut memiliki badan seleksi (selektorat) yang otonom dan terdesentralisasi pada setiap tingkat kepengurusan partai, memiliki prosedur pengambilan keputusan pemilihan kandidat yang mengikutsertakan seluruh anggota partai, serta keterwakilan semua golongan dalam kandidat yang terpilih. Dalam menilai apakah pemilihan kandidat Gubernur dan Wakil Gubernur Sumatera Utara pada Pimilukada Provinsi Sumatara tahun 2018 sudah diselenggarakan PDI Perjuangan secara demokratis atau tidak, penulis akan menelisiknya melalui badan seleksi calon, proses penentuan calon yang berlaku di PDI Perjuangan, serta calon terpilih yakni Djarot Syaiful Hidayat-Dr. Sihar PH. Sitorus. 
Badan Seleksi (Selektorat). Eksistensi badan seleksi (selektorat) dalam pemilihan kandidat merupakan perwujudan demokratisasi partai politik dalam bentuk distribusi kekuasaan/kewenangan partai. Hal ini dimaksudkan untuk meningkatkan dan memperluas dimensi inklusivitas partai dalam proses pengambilan keputusan kandidat partai dalam perhelatan pemilu/pemilukada.

Eksistensi selektorat pada PDI Perjuangan dapat dilihat dalam Peraturan Partai Demokrasi Indonesia Perjuangan Nomor 05 Tahun 2017 Tentang Tim Khusus (Task Force) Partai Demokrasi Indonesia Perjuangan dan Peraturan Partai Demokrasi Indonesia Perjuangan Nomor 24 Tahun 2017 Tentang Rekrutmen dan Seleksi Calon Kepala Daerah dan Wakil Kepala Daerah Partai Demokrasi Indonesia Perjuangan.

Peraturan Partai Demokrasi Indonesia Perjuangan Nomor 05 Tahun 2017 Tentang Tim Khusus (Task Force) PDI Perjuangan menyatakan bahwa Tim Khusus Partai adalah unit kerja yang dibentuk secara khusus oleh DPP dan/atau DPD dan/atau DPC Partai untuk melakukan tugas-tugas spesifik dan strategis dalam rangka menghadapi Pemilukada Serentak 2018 dan Pemilu Serentak 2019 (Pasal 1 ayat 3). Tim khusus ini terdiri dari Tim Khusus Rekrutmen dan Seleksi Calon Kepala Daerah dan Wakil Kepala Daerah, Tim Khusus Rekrutmen dan Seleksi Calon Anggota DPR, DPD dan DPRD Partai, Tim Khusus Verifikasi Partai Sebagai Peserta Pemilu Partai, Tim Khusus Pengawalan Kebijakan dan Program Pemerintah Partai, Tim Khusus Pasukan Siber Partai, Tim Kampanye Nasional Partai, dan Tim Visi Misi Nasional Partai (Pasal 2 ayat 1).

Merujuk pada Peraturan Partai Demokrasi Indonesia Perjuangan Nomor 05 Tahun 2017 tersebut, PDI Perjuangan telah membentuk beberapa selektorat yang pembentukannya dimaksudkan untuk memberikan kewenangan-kewenangan dengan batas tertentu dalam menghadapi pemilihan umum kepala daerah serentak tahun 2018 dan pemilihan umum 2019. Salah satu dari 7 (tujuh) tim khusus yang dibentuk, yakni Tim Khusus Rekrutmen dan Seleksi Calon Kepala Daerah dan Wakil Kepala Daerah, merupakan tim khusus yang berfungsi sabagai selektorat dalam menghadapi pemilihan umum kepala daerah serentak tahun 2018.
Tim Khusus Rekrutmen dan Seleksi Calon Kepala Daerah dan Wakil Kepala Daerah memiliki susunan organisasi dan tata kerja sebagaimana yang dituangkan dalam Peraturan Partai Demokrasi Indonesia Perjuangan Nomor 05 Tahun 2017 pasal 16 ayat 1 s.d 3 yang berbunyi bahwa Tim Khusus Rekrutmen dan Seleksi Calon Kepala Daerah dan Wakil Kepala Daerah Partai adalah unit kerja yang hanya dibentuk ditingkat Pusat dan berkedudukan di Kantor Dewan Pimpinan Pusat Partai, Tim Khusus Rekrutmen dan Seleksi Calon Kepala Daerah dan Wakil Kepala Daerah Partai dibentuk oleh DPP Partai berdasarkan Surat Keputusan DPP Partai, Tim Khusus Rekrutmen dan Seleksi Calon Kepala Daerah dan Wakil Kepala Daerah Partai bertugas membantu DPP Partai dalam hal melaksanakan proses rekrutmen dan seleksi menyangkut kelayakan bakal calon dari hasil penjaringan dan penyaringan, atau bakal calon lain diluar penjaringan dan penyaringan yang diperintahkan oleh DPP Partai dan/atau Ketua Umum Partai.

Apabila kita menilai dari aspek kedudukannya yang hanya dibentuk pada tingkat pengurus pusat, maka tim khusus ini belum memenuhi kaidah desentralisasi kewenangan kepada daerah untuk membentuk tim khusus pemilihan kandidat untuk skala politik lokal. Dengan demikian, keberadaan tim khusus seleksi calon PDI Perjuangan tidak dapat dikatakan demokratis karena belum menerapkan prinsip desentralisasi seperti yang diklaim oleh Rahat dan Hazan (2001) tentang pentingnya pemilihan calon yang dilaksanakan oleh pengurus partai pada level yang mengikuti pemilihan umum. Hal ini menyebabkan pengurus daerah tidak memiliki ruang yang luas dan kewenangan yang mutlak dalam memilih calon yang akan mengikuti pemilihan pada tingkat daerah.

Tim Khusus Rekrutmen dan Seleksi Calon memiliki tugas sebagaimana yang dituangkan dalam Peraturan Partai Demokrasi Indonesia Perjuangan Nomor 05 Tahun 2017 pasal 17 ayat 1 s.d 3 yang berbunyi bahwa Tim Khusus Rekrutmen dan Seleksi Calon bertugas melaksanakan verifikasi dan validasi terhadap dokumen yang diajukan oleh bakal calon; melakukan investigasi, mencari dan mengumpulkan data dan informasi, masukan dan lain-lain terkait rekam jejak bakal calon; melaksanakan diskusi kelompok terarah (FGD) 
dengan kelompok masyarakat tertentu sesuai dengan latar belakang bakal calon; melaksanakan survey internal dan survey eksternal dalam rangka memperoleh data dan informasi menyangkut popularitas dan elektabilitas bakal calon; dan tugas-tugas lain yang diperintahkan secara langsung oleh Kepala Pusat Analisa dan Pengendali Situasi Partai, DPP Partai, dan/atau Ketua Umum Partai.

\section{Meskipun}

pembentukannya dimaksudkan untuk melaksanakan pemilihan calon, namun sesuai dengan pasal 17 peraturan partai nomor 5 tersebut, tim khusus belum mencerminkan keotonoman badan partai seperti yang dipersyaratkan oleh von dem Berge (2013). Menurut pasal 17 tersebut, tim khusus seleksi calon hanya menjalankan tugastugas amdministrasi partai terkait dengan persyaratan calon yang selanjutnya hasil tersebut diserahkan kepada Ketua Umum melalui dewan pimpina pusat partai.

Masih berpedoman pada peraturan tersebut, tim khusus seleksi calon memiliki fungsi sebagai pemberi rekomendasi perihal perbaikan dokumen dari hasil verifikasi dan validasi dokumen; penyedia data dan informasi tentang kelayakan bakal calon berdasarkan hasil investigasi rekam jejak, hasil FGD dan hasil survey yang telah dilaksanakannya (pasal 18 ayat 1). Melihat minimnya fungsi yang dimiliki, tim khusus ini masih sangat jauh dari prisip demokrasi internal partai yang menginginkan kedaulatan dan kewenangan penuh selektorat dalam pemilihan calon seperti yang diklaim Rahat dan Hazan (2001).

Selanjutnya, tim khusus seleksi calon ini juga bersifat ad hoc, dimana masa berlakunya dimulai sejak fase pendaftaran calon sampai calon yang diajukan disahkan (dilantik) menjadi kepala daerah. Hal ini sesuai dengan pasal 19 berbunyi "Tim Khusus Rekrutmen dan Seleksi Calon Kepala Daerah dan Wakil Kepala Daerah Partai bertugas sejak pra penjaringan bakal calon Kepala Daerah dan/atau Wakil Kepala Daerah sampai dengan pelantikan pasangan calon Kepala Daerah dan/atau Wakil Kepala Daerah terpilih. Hal ini tentu bertentangan dengan pandangan von dem Berge (2013) yang menyatakan pentingnya badan-badan partai yang permanen dan otonom dalam mewujudkan partai yang demokratis.
Meskipun telah memiliki selektorat, yakni tim khusus seleksi calon kepala dan wakil kepala daerah, namun PDI Perjuangan belum dapat dikatakan sebagai partai politik yang demokratis sesuai dengan kaidah-kaidah demokrasi internal partai yang diajukan oleh para ilmuwan politik barat kontemporer. Hal ini disebabkan oleh lemahnya kedaulatan yang dimilikinya, minimnya kewenangan yang didelegasikan oleh dewan pimpinan pusat kepadanya, serta eksistensinya yang hanya dibentuk di tingkat dewan pimpinan pusat partai (sentralistis).

Prosedur Seleksi Calon. Sesuai dengan Peraturan Partai Demokrasi Indonesia Perjuangan Nomor 24 Tahun 2017 Tentang Rekrutmen dan Seleksi Calon Kepala Daerah dan Wakil Kepala Daerah, prosedur seleksi yang belaku di PDI Perjuangan terdiri dari beberapa tahapan yakni pengumuman seleksi, penjaringan calon, verifikasi calon tingkat DPD, verifikasi calon oleh tim khusus seleksi calon, penyaringan calon oleh DPP, dan penetapan calon oleh DPP partai.

Penjaringan Calon. Pada tahap pertama yakni penjaringan calon, DPD penyelenggara seleksi calon terlebih dahulu melaksanakan pengumuman tentang kegiatan seleksi calon kepala daerah dan atau wakil kepala daerah. Hal ini sesuai dengan pasal 10 berbunyi Penjaringan bakal calon dilaksanakan sekurang-kurangnya 12 (dua belas) bulan sebelum batas akhir pendaftaran pasangan calon berdasarkan tahapan penyelenggaraan pemilihan kepala daerah yang ditetapkan dalam Peraturan KPU; Dewan pimpinan partai pada tingkatannya menyampaikan pemberitahuan/ pengumuman resmi ke seluruh jajaran legislatif, eksekutif, kader, pengurus, anggota, dan simpatisan partai, serta masyarakat luas secara terbuka di wilayahnya tentang penjaringan bakal calon jika perolehan suara partai antara $15 \%$ - $24 \%$ atau perolehan kursi partai antara $10 \%$ - 19\% pada pemilu legislatif terakhir; Dewan pimpinan partai pada tingkatannya menyampaikan pemberitahauan/ pengumuman resmi ke seluruh jajaran legislatif, eksekutif, kader, pengurus, anggota, dan simpatisan partai secara tertutup tentang penjaringan bakal calon jika perolehan suara partai lebih dari $25 \%$ atau perolehan kursi partai lebih dari $20 \%$ pada pemilu legislatif terakhir. 
Merujuk pada pasal ini, seleksi calon kepala daerah dilaksanakan minimal 12 (dua belas) bulan sebelum pendaftaran calon ke KPU penyelenggara ditutup. Publikasi rekrutmen dan seleksi calon dilaksanakan dengan dua cara yakni pengumuman terbuka dan pengumuman tertutup. Apabila DPD penyelenggara seleksi calon tidak memenuhi kuota pengajuan calon sesuai dengan aturan formal pencalonan, maka pengumuman dilaksanakan secara terbuka kepada seluruh anggota partai, pengurus partai, bahkan kepada seluruh warga masyarakat. Sebaliknya, apabila DPD penyelenggara seleksi calon memenuhi kuota pengajuan calon, maka pengumuman rekrutmen dan seleksi calon kepala daerah hanya disampaikan kepada anggota dan pengurus partai. Dengan kata lain, apabila PDI Perjuangan memenuhi kuota pencalonan kepala daerah di daerah penyelenggara Pemilukada, maka pengumuman dilaksanakan secara tertutup.

Dari kedua tata cara pengumunan seleksi tersebut di atas, kita dapat memahami bahwa PDI Perjuangan akan menghindari keterbukaan informasi tentang seleksi calon ketika DPD penyelenggara memenuhi kota pencalonan (tanpa koalisi dengan partai lain). Hal ini tentu bertentangan dengan pandangan Scarrow (2005) yang menyatakan pentingnya inklusivitas dalam mewujudkan demokrasi di internal partai.

Selanjutnya, DPD penyelenggara seleksi calon melaksanakan penjaringan calon sesui dengan amanat pasal 11 berbunyi Penjaringan bakal calon kepala daerah/ wakil kepala daerah provinsi dan kebupaten/ kota dilakukan secara berjenjang; Penjaringan bakal calon kepala daerah/ wakil kepala daerah provinsi oleh DPD Partai dengan ketentuan setiap DPD Partai di provinsi tersebut mengusulkan sebanyakbanyaknya 2 (dua) bakal calon kepala daerah/ wakil kepala daerah.

Dalam melaksanakan penjaringan, DPD penyelenggara seleksi calon juga menempuh dua cara yakni penjaringan terbuka dan penjaringan tertutup. Sesuai dengan pasal 12 bahwa Dalam proses penjaringan terbuka, setiap bakal calon kepala daerah/ wakil kepala daerah kabupaten/ kota wajib mengambil dokumen pendaftaran yang terdiri dari 1) Formulir pendaftaran, 2) Formulir biodata, 3) Surat pernyataan kemampuan financial, 4) Surat pernyataan komitmen politik, dan 5)
Formulir visi misi bakal calon sesuai dengan format yang disediakan di Kantor DPC, DPD, atau DPP Partai; Dalam proses penjaringan terbuka, setiap bakal calon kepala daerah/ wakil kepala daerah provinsi wajib mengambil dokumen pendaftaran yang terdiri dari 1). Formulir pendaftaran, 2). Formulir biodata, 3). Surat pernyataan kemampuan financial, 4). Surat pernyataan komitmen politik, dan 5). Formulir visi misi bakal calon sesuai dengan format yang disediakan di Kantor DPD atau DPP Partai; Dalam waktu paling lama 2 (dua) minggu setelah pengambilan dokumen pendaftaran sebagaimana dimaksud ayat 1 dan ayat 2, bakal calon menyerahkan kembali kepada DPC Partai untuk tingkat kabupaten/ kota atau kepada DPD Partai untuk provinsi dengan melampirkan dokumen pendukung sebagai bukti otentik atas seluruh keterangan yang diberikan.

Sementara penjaringan tertutup dilaksanakan sesuai dengan amanat pasal 13 berbunyi Dalam proses penjaringan tertutup, setiap bakal calon kepala daerah dan/atau wakil kepala daerah kabupaten/kota wajib mengambil dokumen pendaftaran yang terdiri dari 1) Formulir pendaftaran, 2) Formulir biodata, 3) Surat pernyataan kemampuan financial, 4) Surat pernyataan komitmen politik, dan 5) Formulir visi misi bakal calon sesuai dengan format yang disediakan di Kantor DPC, DPD, atau DPP Partai; Dalam proses penjaringan tertutup, setiap bakal calon kepala daerah/ wakil kepala daerah provinsi wajib mengambil dokumen pendaftaran yang terdiri dari 1) Formulir pendaftaran, 2) Formulir biodata, 3) Surat pernyataan kemampuan financial, 4) Surat pernyataan komitmen politik, dan 5) Formulir visi misi bakal calon sesuai dengan format yang disediakan di Kantor DPD atau DPP Partai.

Ketika penyelenggaraan penjaringan tidak mendapatkan dua calon, maka perpanjangan pendaftaran akan dilakukan seperti yang diamanatkan Pasal 14 berbunyi Dalam hal bakal calon yang mengembalikan formulir sebagaimana dimaksud pasal 12 kurang dari 2 bakal calon kepala daerah dan/atau bakal calon wakil kepala daerah maka masa pendaftaran diperpanjang selama 14 hari kerja; Dalam hal jumlah bakal calon setelah perpanjangan tetap kurang dari 2 bakal calon, maka Dewan Pimpinan Partai pada 
tingkatannya melakukan verifikasi dan validasi dokumen bakal calon.

Selanjutnya, DPD partai mengadakan musyawarah untuk melakukan verifikasi calon sesuai dengan amanat pasal 15 yang berbunyi Rapat Dewan Pimpinan Partai pada tingkatannya melakukan verifikasi dan validasi dokumen bakal calon. Verifikasi dan validasi dokumen dimaksud dilakukan dengan meneliti kebenaran dan keabsahan atas seluruh kelengkapan persyaratan bakal calon kepala daerah dan/atau wakil kepala daerah sebagaimana diatur dalam perautaran perundang-undangan yang mengatur tentang Pemilihan Kepala Daerah dan Wakil Kepala Daerah. Pada saat verifikasi dan validasi dokumen dilakukan, Rapat Partai juga melakukan evaluasi terhadap komitmen bakal calon kepada Partai serta menganalisa kekuatan dukungan kekuatan politik/ ketokohan bakal calon.

Dalam melakukan verifikasi, validasi dokumen, dan evaluasi terhadap bakal calon, Dewan Pimpinan Partai pada tingkatannya dapat meminta keterangan secara tertulis dari pihak lain sebagai tambahan informasi terhadap bakal calon. Hasil verifikasi dan validasi dokumen bakal calon pada tingkat kabupaten/kota disampaikan kepada DPD Partai untuk dilakukan verifikasi dan validasi lanjutan dan kemudian meeruskannya kepada DPP Partai melalui Tim Khusus Rekrutmen dan Seleksi Calon Kepala Daerah dan Calon Wakil Kepala Daerah Partai untuk dilakukan verifikasi dan validasi. Verifikasi dan validasi bakal calon tingkat provinsi dilakukan oleh DPD Partai dan disampaikan ke DPP Partai melalui Tim Khusus Rekrutmen dan Seleksi Calon Kepala Daerah dan Wakil Kepala Daerah Partai untuk dilakukan verifikasi dan validasi tingkat akhir.

Verifikasi dan Validasi Calon. Setelah menerima dokumen calon yang diajukan oleh DPD Partai, selanjutnya DPP Partai melakukan evaluasi terhadap hasil verifikasi dan validasi yang sudah dilaksanakan oleh DPD Partai. Hal ini sesuai dengan Pasal 17 yang menyatakan bahwa DPP Partai melakukan evaluasi terhadap hasil verifikasi dan validasi dokumen yang dilakukan oleh DPC dan DPD Partai terhadap bakal calon kepala daerah dan/atau wakil kepala daerah. Pelaksanaan evaluasi dimaksud dilakukan oleh Tim Khusus Rekrutmen dan Seleksi Calon Kepala Daerah dan Wakil Kepala Daerah Partai yang dibentuk oleh DPP Partai. Apabila ditemukan penyimpangan terhadap ketentuan yang berlaku di dalam partai dalam pelaksanaan evaluasi, maka Tim Khusus akan memberikan rekomendasi kepada DPP Partai untuk memerintahkan DPD Partai dan DPC Partai untuk memperbaiki hasil verifikasi dan validasi dokumen bakal calon yang diajukan.

Dalam melaksanakan evaluasi terhadap hasil verifikasi dan validasi calon yang diajukan oleh DPD Partai, Tim Khusus partai akan menempuh beberapa langkah sesuai dengan yang diatur di dalam pasal 18 yang menyatakan bahwa Tim khusus Partai melaksanakan survey internal dan/ atau eksternal sebelum dan sesudah dilaksanakannya tahap penjaringan serta sebelum dan sesudah penyaringan. Survey internal dimaksud dilaksanakan oleh tim khusus dengan menggerakkan saksi dan gugus tugas penggerak pemilih (guraklih) partai. Selain survey internal, tim khusus partai juga melaksanakan survey eksternal dengan cara menunjuk konsultan/lembaga survey yang kredibel, profesional, dan independen, baik yang berada di tingkat pusat maupun daerah yang telah ditetapkan oleh DPP Partai.

Selain pelaksanaan survey internal dan eksternal, tim khusus juga melakukan pemetaan politik dan penelusuran bakal calon. Pemetaan politik dimaksud dilaksanakan oleh DPC dan DPD Partai berdasarkan formulir yang telah disediakan oleh tim khusus partai. Untuk mendapatkan informasi yang lebih akurat, tim khusus partai juga melakukan penelusuran terhadap rekam jejak bakal calon.

\section{Mekanisme Pengambilan Keputusan}

Calon. Ada tiga mekanisme pengambilan keputusan bakal calon menjadi calon kepala daerah dan wakil kepala daerah yang dianut oleh PDI Perjuangan sesuai dengan peraturan partai nomor 24 tahun 2017. Mekanisme yang pertama dilakukan oleh DPP dengan berpedoman pada pasal 9 ayat 1 yang menyatakan bahwa partai menugaskan angota atau kader partai sebagai calon kepala daerah dan/atau wakil kepala daerah dengan cara mengusung sendiri atau mengusung dengan dukungan partai politik lain apabila; a). Perolehan suara Partai 25\% (dua puluh lima persen) ke atas atau perolehan kursi Partai 20\% ke atas; b). Kepala Daerah petahana adalah kader partai yang berhasil menjalankan pemerintahan dengan baik pada 
periode sebelumnya; c). Memiliki basis pemilih tradisional yang kuat; d). Didukung oleh data dan informasi kelayakan calon serta hasil pemetaan politik yang memadai; e). Struktur Partai sampai tingkat Pengurus Ranting atau Pengurus Anak Ranting solid dan kuat; f). Calon Kepala Daerah dan/atau Calon Wakil Kepala Daerah harus anggota atau kader Partai, kecuali atas dasar kepentingan strategis Partai diputuskan lain oleh Ketua Umum Partai atau DPP Partai.

Selanjutnya mekanisme kedua pengambilan keputusan calon didasarkan pada ayat 2 pasal 9 yang menyatakan bahwa partai menugaskan Anggota atau kader Partai sebagai Calon Kepala Daerah atau Calon Wakil Kepala Daerah melalui suatu koalisi dengan Partai Politik lain apabila; a). Perolehan suara Partai antara $15 \%$ (lima belas persen) sampai $24 \%$ (dua puluh empat persen) atau perolehan kursi Partai antara $10 \%$ (sepuluh persen) sampai $19 \%$ (sembilan belas persen); b). Memiliki basis pemilih tradisional yang kuat; c) Didukung oleh data dan informasi kelayakan calon serta hasil pemetaan politik yang memadai; d). Struktur Partai sampai tingkat Pengurus Ranting atau Pengurus Anak Ranting solid dan kuat; dan e). Setidak-tidaknya calon Kepala Daerah dan Calon Wakil Kepala Daerah adalah anggota atau kader Partai, kecuali atas dasar kepentingan strategis Partai diputuskan Ketua Umum Partai atau DPP Partai.

Mekanisme ketiga dalam penetapan calon sesuai dengan pasal 9 ayat 3 yang menyatakan bahwa partai menugaskan anggota partai sebagai calon kepala daerah dan/atau wakil kepala daerah atau mendukung Pasangan Calon Lain yang kuat apabila; a). Perolehan suara Partai di bawah 15\% (lima belas persen) atau perolehan kursi Partai di bawah $10 \%$ (sepuluh persen); b). Didukung oleh data dan informasi kelayakan calon serta hasil pemetaan politik yang memadai; c). Tidak memiliki basis Partai yang kuat namun struktur Partai sampai tingkat Pengurus Ranting atau Pengurus Anak Ranting solid dan kuat; d). Apabila pasangan calon adalah bukan anggota partai maka harus memiliki visi misi yang tidak bertentangan dengan visi misi nasional Partai.

Ketiga mekanisme pengambilan keputusan penetapan calon diatas harus mempertimbangkan ketentuan-ketentuan lanjutan seperti yang diamanatkan pasal 9 yang menyatakan bahwa; penentuan calon juga harus mempertimbangkan soliditas internal Partai, dan kemampuan di dalam menyediakan sumber daya untuk pemenangan Pemilukada (ayat 4); Setiap anggota atau kader partai yang diusung maupun didukung partai sebagai calon Kepala Daerah dan/atau Wakil Kepala Daerah wajib menandatangani surat pernyataan sebagai petugas Partai (ayat 5); Dalam hal tidak adanya calon yang diajukan dari internal Partai, maka calon yang diusung Partai wajib melakukan komitmen politik secara tertulis dengan partai yang mencakup komitmen untuk melaksanakan sikap politik dan program perjuangan Partai, termasuk penempatan anggota atau kader Partai di jabatan strategis di bawah kepemimpinannya (ayat 6); Dalam hal calon berasal dari internal Partai dan memenuhi kelayakan didukung oleh internal dan eksternal Partai namun tidak memiliki kecukupan sumber daya untuk memenangkan Pemilukada dan/atau terkait dengan kepentingan strategis Partai, Dewan Pimpinan Partai menggalang dana gotongroyong untuk memenangkan calon tersebut (ayat 7).

Dalam konteks demokrasi, rekrutmen kandidat pejabat publik merupakan peran yang paling fundamental yang dimainkan oleh partai politik dalam fungsinya sebagai penghubung antara warga negara dengan negara. Oleh karena itu, pada prinsipnya suatu proses rekrutmen yang demokratis harus memberikan kesempatan yang sama dan seluas-luasnya bagi setiap individu untuk bergabung, bersaing (kompetisi), dan dapat menduduki jabatan politik maupun jabatan pemerintahan bagi setiap warga negara. Selanjutnya, keterbukaan peluang itu akan memberikan kesempatan tidak hanya kepada warga Negara, namun juga kepada partai politik untuk menempatkan orang-orang baik kader partai maupun non kader partai untuk menempati jabatan strategis di pemerintahan yang pada akhirnya akan merepresentasikan partai itu sendiri di pemerintahan.

Dalam upaya pencarian kader maupun non kader terbaik, partai politik selanjutnya membuat persyaratan-persyaratan tertentu yang mesti dipenuhi oleh setiap individu yang berkeinginan untuk direkrut sebagai kandidat. Persyaratan-persyaratan tersebutlah yang diterapkan oleh partai politik dengan 
pertimbangan-pertimbangan yang objektif dan rasional sesuai aturan yang berlaku baik dalam ketentuan hukum formal maupun ketentuan partai demi mendapatkan kandidat terbaik untuk diajukan di dalam pemilihan umum.

Sama halnya dengan PDI Perjuangan, dalam menyelenggarakan penjaringan dan penyaringan bakal calon Kepala Daerah dan/atau bakal calon Wakil Kepala Daerah sebagai salah satu fungsi utama partai politik, dewan pimpinan partai pada setiap tingkatannya memberikan peluang yang sebesar-besarnya kepada seluruh anggota partai untuk dicalonkan. Dalam rangka mendapatkan calon terbaik, baik dari aspek kapasitas, kapabilitas maupun elektabilitas calon, PDI Perjuangan juga memberlakukan persyaratan-persyaratan sesuai dengan karakteristik yang sudah ditetapkan partai.

Ketika PDI Perjuangan tidak mecapai kuota pencalonan secara mandiri (tanpa koalisi dengan partai lain), maka PDI Perjuangan akan memberikan peluang yang seluas-luasnya bagi seluruh anggota partai, masyarakat non partisan, dan bahkan bagi kader partai lain untuk dicalonkan sebagai calon kepala dan atau wakil kepala daerah. Dengan kata lain, ketika persyaratan kuota pencalonan PDI Perjuangan tidak terpenuhi untuk mengajukan calon secara mandiri, maka partai akan membuka peluang untuk membentuk koalisi demi mencapai kuota pencalonan di daerah yang menyelenggarakan Pemilukada. Namun apabila kuota pencalonan dapat dipenuhi oleh PDI Perjangan secara mandiri, maka pencalonan akan memprioritaskan kader murni PDI Perjuangan dengan melakukan perekrutan calon dari kader-kader partai yang paling berpeluang untuk memenangkan pemilihan umum untuk dicalonkan secara tertutup.

Apabila ditinjau dari perspektif inklusifitas partai dimana seluruh warga masyarkat berkesempatan menjadi kandidat pejabat publik sebagaimana yang dikemukakan Scarrow (2015), PDI Perjuangan belum dapat dikatakan demokrtais. Keterbukaan rekrutmen calon dilaksanakan hanya pada saat partai tidak memenuhi kuota pencalonan mandiri (tanpa koalisi partai lain). Dengan kata lain, tingkat demokrasi PDI Perjuangan dalam pemberian kesempatan kepada seluruh warga negara untuk menduduki jabatan publik masih sangat rendah. Hal ini tentu sangat bertentang dengan prinsip-prinsip dasar demokrasi yang mengutamakan persamaan dan keterbukaan bagi seluruh warga Negara, terutama dalah hal kesempatan untuk menduduki jabatan publik.

Pencalonan kandidat kepala dan wakil kepala daerah dimulai dengan penetapan persyaratan-persyaratan yang harus dipenuhi oleh setiap orang, baik yang berasal dari kader internal partai, dari partai lain maupun non partisan. Pemenuhan terhadap seluruh persyaratan yang sudah ditetapkan selanjutnya akan dievaluasi dan disahkan oleh dewan pengurus daerah penyelenggara rekrutmen calon. Pasangan calon yang diajukan oleh pengurus daerah tersebut selanjutnya diverifikasi dan divalidasi oleh badan partai non pilihan, yakni tim khusus partai. Selanjutnya, pasangan calon yang sudah divalidasi oleh tim khusus partai diserahkan kepada pemimpin partai yakni Ketua Umum untuk ditetapkan dan disahkan sebagai pasangan calon yang diusung dalam pemilukada. Pengambilan keputusan tentang calon dilaksanakan oleh ketua umum secara tertutup dengan hanya melibatkan elite dewan pengurus pusat.

Hal ini selaras dengan penyataan Ketua Umum PDI Perjuangan, Megawati Soekarno Putri yang dikutip dari Harian Kompas terkait dengan pencalonan gubernur Sumatera Utara dalam pemilukada tahun 2018. Menurut Megawati, pencalonan Djarot sebagai calon gubernur Sumatera Utara merupakan hasil diskusinya dengan Sekretaris Jenderal PDI Perjuanga, Hasto Kristyianto. Dalam diskusi itu, Megawati mengajukan beberapa pertanyaan kepada Hasto. "Saya bilang ke Hasto, 'To kenapa kita enggak lihat orang di dekat kita? Pada kesempatan itu, Hasto justru bertanya kepada Megawati, "Siapa bu?" Sang Ketua Umum pun memberikan jawaban yang sesungguhnya di luar perkiraan Hasto, "Djarot". Hasto pun merespon Megawati dengan jawaban, "Iya ya, kok ibu brilian?. Demikian Megawati menuturkan proses pemilihan Djarot sebagai calon gubernur yang akan diusung oleh PDI Perjuangan pada Pemilukada Sumatera Utara tahun 2018.

Dari paparan di atas, kita dapat melihat bagaimana dominasi Ketua Umum dan elite partai dalam pengambilan keputusan calon kepala daerah. Keputusan pencalonan diambil Ketua Umum hanya melalui satu diskusi yang bersifat ringan dengan Sekretaris Jenderal Partai. Bahkan di dalam diskusi itupun, 
Sekretaris Jenderal tidak menunjukkan perbedaan pandangan dengan Ketua Umum, atau minimal mengajukan suatu argumentasi yang mendasari Ketua Umum dalam memilih Djarot menjadi calon gubernur. Tentu hal itu merupakan suatu indikasi yang menunjukkan bahwa perbedaan pendangan atau pendapat tidak memiliki ruang yang luas dalam PDI Perjuangan. Pandangan Ketua Umum seolah menjadi suatu keputusan mutlak yang harus dilaksanakan oleh seluruh lapisan partai.

Ditinjau dari perspektif metode pengambilan keputusan pencalonan kandidat yang dilaksanakan, PDI Perjuangan belum dapat dikatakan demokratis sesuai dengan pandangan Scarrow (2005) yang menyatakan bahwa, proses pengambilan keputusan yang demokratis harus melibatkan semacam permusyawaratan dalam mengambil suatau keputusan. Pemungutan suara (baik secara tertutup maupun terbuka) merupakan syarat mutlak yang diperlukan sesuai dengan prinsip dasar demokrasi. Berbeda dengan pandangan Scarrow, pengambilan keputusan bakal calon menjadi calon di dalam PDI Perjuangan dilaksanakan tanpa melalui suatu proses musyarawarah ataupun semacam pemungutan suara. Proses pengambilan keputusan tidak ditempuh dengan melibatkan anggota dan simpatisan partai. Penentuan bakal calon menjadi calon dilakukan oleh Ketua Umum secara tertutup bersama-sama dengan elite partai. Transparansi proses pengambilan keputusan bakal calon menjadi calon yang diusung sebagaimana yang diajukan von dem Berge dkk (2013) tidak disajikan, baik kepada dewan pimpinan partai ataupun kepada anggota dan simpatisan partai.

Dominasi Ketua Umum dalam pengambilan keputusan pencalonan kandidat dalam PDI Perjuangan sejalan dengan temuan penelitian Herri Junius Nge (2017) yang menyatakan bahwa kekuasaan formal ketua umum sebagai struktur tertinggi dalam partai memiliki kewenangan yang sangat luas dan bersifat mutlak dalam pengambilan kebijakan partai, termasuk dalam memutuskan calon kepala daerah. Kesimpulan Nge tersebut dapat dilihat dalam Mukadimah PDI Perjuangan yang menyatakan bahwa ketua umum memiliki hak prerogatif untuk menentukan demokrasi dalam penyelenggaraan roda pemerintahan partai. Selain hak prerogatif dalam menentukan demokrasi internal partai yang dijamin mukadimah partai, Ketua Umum juga memiliki hak istimewa dalam menentukan calon kepala daerah yang akan diusung atau didukung partai dalam suatu perhelatan Pemilukada yang dijamin oleh anggaran dasar partai.

Penetapan Calon. Mekanisme penetapn calon kepala daerah dan/atau wakil kepala daerah dalam PDI Perjuangan ditempuh sesuai dengan amanat peraturan partai nomor 24 tahun 2017 pasal 1 ayat 16 yang yang menyatakan bahwa penetapan dan pengesahan bakal calon kepala daerah dan/atau wakil kepala daerah menjadi calon kepala daerah dan/atau wakil kepala daerah oleh DPP Partai melalui Surat Keputusan DPP Partai yang merekomendasikan calon kepala daerah dan/atau wakil kepala daerah.

Sebelum calon ditetapkan oleh DPP, tim khusus partai terlebih dahulu melakukan verifikasi dan validasi terhadap bakal calon sesuai dengan amanat pasal 20. Setelah tim khusus partai menyelesaikan evaluasi terhadap bakal calon yang diajukan oleh DPD Partai, maka nama-nama hasil penjaringan yang sudah diperoleh selanjutnya disampaikan kepada DPP Partai untuk dilakukan penyaringan dengan pertimbangan data dan informasi kelayakan bakal calon yang telah disusun Tim Khusus, pemetaan politik, berita acara rapat DPC dan DPD Partai, hasil tes tertulis, hasil tes psikologi, hasil wawancara, komitmen politik calon, dan kesediaan calon untuk menandatangani surat pernyataan sebagai Petugas Partai yang ditandatangani di atas materai, bagi calon yang berstatus sebagai anggota/kader Partai.

Bagi DPD yang perolehan suaranya 15\% ke atas atau perolehan kursinya $10 \%$ ke atas pada pemilu legislatif terakhir, calon yang berstatus non kader Partai juga harus menandatangani surat pernyataan kesediaan sebagai petugas Partai. Surat Pernyataan yang sudah ditandatangani tersebut menjadi satu kesatuan yang tak terpisahkan dari Surat Keputusan DPP Partai tentang penetapan calon. Pasangan calon yang ditetapkan oleh DPP didasarkan pada nama-nama hasil penyaringan yang diajukan oleh tim khusus partai, dan dalam keadaan luar biasa DPP Partai dapat menetapkan calon di luar dari yang diusulkan melalui tahapan sebelumnya. Keadaan luar biasa dimaksud didasarkan pada pertimbangan ketiadaan calon yang diajukan oleh DPD Partai, terjadinya pelanggaran terhadap ketentuan 
yang termuat di dalam Peraturan Partai yang mengakibatkan kondisi yang merugikan atau membahayakan Partai sebagaimana yang tertuang pada pasal 49 Anggaran Rumah Tangga Partai, tidak berjalannya mekanisme organisasi yang berakibat tidak adanya pasangan calon yang memenuhi kriteria hingga batas akhir waktu pendaftaran, dan/atau pertimbangan khusus oleh Ketua Umum Partai.

Calon yang sudah disaring oleh DPP Partai ditetapkan dan disahkan dengan Surat Keputusan sebagai Pasangan Calon untuk kemudian diserahkan kepada DPD Partai untuk didaftarkan ke KPU Provinsi yang bersangkutan. Seluruh jajaran kepengurusan Partai, anggota dan kader Partai, komite Partai, komunitas juang, satuan tugas Partai serta Alat Kelengkapan Partai wajib memperjuangkan calon yang sudah ditetapkan DPP Partai dalam rangka pemenangan Pasangan Calon. Menurut pasal 21 bahwa pasangan calon yang telah ditetapkan oleh DPP Partai wajib mengikuti Sekolah Partai.

Setelah DPP Partai menetapkan dan mengesahkan pasangan calon yang akan diusung atau didukung partai dalam perhelatan Pemilukada maka DPD Partai akan menyelenggarakan Rapat Kerja Daerah Khusus (Rakerdasus) sesuai dengan amanat pasal 22 yang menyatakan bahwa rakercabsus dan/ atau Rakerdasus Partai diselenggarakan setelah DPP Partai menetapkan dan mengesahkan calon kepala daerah dan/atau wakil kepala daerah dengan Surat Keputusan DPP Partai tentang Pasangan Calon Kepala Daerah dan/atau Wakil Kepala Daerah yang diusung dan/atau didukung Partai.

Penyelenggaraan

Rakerdasus dimaksudkan untuk memberikan ruang dan tempat kepada pasangan calon yang ditetapkan dan disahkan oleh DPP Partai untuk menyosialisasikan visi dan misinya kepada pengurus partai di daerah sesuai dengan amanat pasal 24 ayat 3 yang menyatakan bahwa Calon Kepala Daerah dan/atau Wakil Kepala Daerah Provinsi yang telah ditetapkan dan disahkan DPP Partai menyampaikan komitmen politik, surat pernyataan sebagai Petugas Partai, dan visi misi pasangan calon melalui Rakerdasus Partai yang dihadiri oleh DPC Partai. Dalam ayat 4 dinyatakan bahwa di dalam Rakerdasus Partai sebagaimana yang dimaksud pada ayat 3, Dewan Pimpinan Partai menyampaikan rekam jejak pasangan calon dan strategi pemenangan Pemilukada berbasis kekuatan sumber daya politik Partai.

Pelaksanaan rakerdasus didasarkan pada pasal 26 yang menyatakan bahwa rakerdasus diselenggarakan oleh DPD Partai, rakerdasus dipimpin oleh DPP Partai, peserta Rakerdasus adalah Ketua dan Sekretaris PAC, seluruh Pengurus DPC Partai dan seluruh Pengurus DPD Partai. Seluruh Petugas Partai di kabupaten/kota yang bersangkutan dan anggota Fraksi Partai DPRD kabupaten/kota yang bersangkutan, DPRD provinsi yang bersangkutan, dan DPR RI yang berasal dari daerah pemilihan di provinsi bersangkutan diwajibkan hadir dalam Rakerdasus Partai. Terkait dengan pembiayaannya, penyelenggaraan rakerdasus berpedoman pada pasal 27 yang menyatakan bahwa pelaksanaan Rakercabsus dan Rakerdasus Partai dilaksanakan secara gotong royong. Calon kepala daerah dan/atau wakil kepala daerah membantu pelaksanaan Rakercabsus atau Rakerdasus dengan membantu dan gotong royong yang diserahkan kepada Bendahara Partai.

Dari paparan di atas kita dapat melihat bahwa penetapan calon dilakukan oleh dewan pengurus pusat dengan cara menunjuk bakal calon atas dasar pertimbangan dari berbagai aspek yang sudah dianalisa oleh Tim Khusus Partai. Dalam hal tertentu, dewan pengurus pusat atau ketua umum dapat menunjuk calon di luar dari calon yang diajukan oleh dewan pengurus daerah. Penunjukan calon di luar calon yang diajukan pengurus daerah dimaksudkan untuk menjaga stabilitas partai pada tingkat kepengurusan daerah atau kepentingan strategis partai yang bersifat nasional berdasarkan perhitungan ketua umum. Penunjukan tersebut dilaksanakan melalui penerbitan surat rekomendasi tentang penetapan calon yang ditujukan kepada dewan pengurus daerah untuk dilaksanakan dan diperjuangkan untuk pemenangannya dalam pemilukada. Surat rekomendasi tersebut bersifat final dan tidak dapat diganggugugat oleh dewan pengurus daerah. Pengurus daerah hanya diberikan ruang untuk menetapkan dan menyosialisasikan calon yang ditetapkan oleh DPP melalui suatu rapat kerja khusus.

Apabila ditelisik lebih mendalam, pasal 1 ayat 16 peraturan partai nomor 24 tersebut, penetapan calon dilakukan oleh dewan 
pengurus partai melalui penerbitan surat rekomendasi. Hal ini menunjukkan bahwa penetapan calon kepala daerah masih bersifat sentralistis dan tertutup. Dewan pengurus daerah sama sekali tidak diikutsertakan dalam menetapkan calon yang akan diajukan dalam pemilukada. Aspirasi politik lokal dapat diabaikan oleh pengurus pusat dengan mengedepankan kepentingan politik nasional partai. Desentralisasi kewenangan sebagai suatu perwujudan demokrasi politik dalam partai, khususnya dalam pemeilihan pejabat publik daerah sama sekali tidak diberikan kepada dewan pengurus daerah. Dalam hal pemilukada provinsi Sumatera Utara tahun 2018, DPP PDI Perjuangan menetapkan pasangan calon dimana calon gubernur dan calon wakil gubernur yang ditetapakan berasal dari kader partai yang tercatat sebagai pengurus pusat PDI Perjuangan, yakni Djarot Syaiful Hidayat dan Sihar PH. Sitorus. Penetapan kedua calon tersebut lebih didasarkan pada kepentingan politik PDI Perjuangan terhadap Provinsi Sumatera Utara yang dianggap sebagai salah satu basis suara partai dalam setiap perheletan pemilihan umum, baik pemilihan umum nasional maupun pemilihan umum lokal (Pilpres, Pileg, dan Pemilukada).

Merujuk pada kaidah prosedur seleksi calon kepala daerah dan wakil kepala daerah yang berlaku di PDI Perjuangan sebagaimana yang disajikan di atas, kita dapat melihat bahwa seleksi calon dilaksanakan secara berjenjang dan bertahap. Jenjang pertama dilaksanakan di dewan pimpinan daerah, dalam hal ini, DPD PDI Perjuangan Sumatera Utara selaku DPD yang sedang mengikuti perhelatan Pemilukada terlebih dahulu melakukan penjaringan awal yang selanjutnya diajukan kepada DPP Partai melalui Tim Khusus Rekrutmen Calon Kepala Daerah. Selanjutnya seleksi calon dilakukan pada jenjang kedua, yakni pada DPP Partai. Pelaksanaan seleksi pada jenjang DPP dilakukan secara bertahap, dimulai dari penugasan Tim Khusus Partai untuk melakukan evaluasi memalui survey dan pemetaan politik terhadap calon yang sudah diajukan oleh DPD PDI Perjuangan Sumatera Utara. Pelaksanaan evaluasi oleh Tim Khusus Partai juga dilaksanakan secara bertahap demi memperoleh informasi yang akurat dan valid terhadap calon yang akan ditetapkan dan disahkan oleh DPP Partai. Selanjutnya, hasil evaluasi yang dilakukan oleh Tim Khusus Partai diserahkan kepada DPP Partai untuk ditatapkan dan disahkan oleh DPP Partai menjadi kandidat kepala daerah yang diusung oleh PDI Perjuangan pada Pemilukada Sumatara Utara tahun 2018.

Prosedur seleksi calon di atas tentu sangat berbeda dengan prosedur yang dicitacitakan oleh para penggagas demokrasi internal partai. Apabila kita merujuk pada indikator demokratis atau tidaknya suatu proses seleksi calon yang diterapkan pada suatu partai politik yang dikemukakan oleh Rahat dan Hazan (2001), yakni pencalonan atau kandidasi (khusus anggota partai atau terbuka untuk masyarakat luas), selektorat (otonom atau tidak), desentralisasi dalam pencalonan (dilakukan di dewan pengurus daerah), dan sistem penentuan kandidat (apakah melalui pemungutan suara atau penghunjukan/pengangkatan), tentu prosedur yang diterapkan oleh PDI Perjuangan dapat dikatakan belum demokratis, atau dengan kata lain, tingkat demokrasi dalam seleksi calonnya masih rendah.

Dari keempat aspek yang dikemukakan oleh Rahat dan Hazan (2001), tidak satu pun aspek yang dipenuhi prosedur yang diterapkan oleh PDI Perjuangan. Dari aspek pencalonan, PDI Perjuangan hanya memberikan kesempatan untuk menjadi calon kepala daerah kepada masyarakat umum ketika kuota pencalonan secara mandiri sesuai dengan ketentuan peraturan perundang-undanga tidak terpenuhi di daerah bersangkutan. Ketika kuota pencalonan tersebut terpenuhi, maka PDI Perjuangan akan melakukan seleksi tertutup yang dikhususkan kepada kader partai. Dengan demikian, prosedur pencalonan yang diterapkan oleh PDI Perjuangan tidak memenuhi aspek inklusivitas dalam pemberian kesempatan menjadi calon kepala daerah kepada seluruh masyarakat.

Dari aspek desentralisasi pelaksanaan seleksi calon, PDI Perjangan juga belum dapat dikatakan demokratis. Suatu proses seleksi yang demokratis menurut Rahat dan Hazan (2001) harus terdesentralisasi sepenuhnya kepada dewan kepengurusan daerah. Daerah harus diberikan kesempatan untuk membangun seluruh aspek partai pada tingkat daerah. Salah satu aspek paling strategis di daerah adalah pemilihan kandidat pejabat publik pada tingkat daerah. Menilik pada 
aturan partai sebagaimana yang dijabarkan di atas, PDI Perjuangan tidak menerapkan aspek desentralisasi kewenangan kepada DPD, khususnya dalam pemilihan calon gubernur dan calon gubernur yang akan diusung oleh PDI Perjuangan dalam perhelatan Pemilukada Sumatara Utara tahun 2018. DPD dalam hal ini, DPD PDI Perjuangan Sumatera Utara hanya melakukan penjaringan bakal calon yang selanjutnya diusulkan kepada DPP Partai.

Dari aspek selektorat, PDI Perjuangan juga belum menerapkan demokrasi internal partai. Masih menurut Rahat dan Hazan (2001), selektorat yang demokratis harus memiliki otonomi yang luas dan terdesentralisasi pada setiap tingkat kepengurusan partai. Tim Khusus Seleksi Calon Kepala Daerah PDI Perjuangan selaku selektorat hanya dibentuk di DPP Partai. Di samping itu, Tim khusus ini, juga tidak memiliki otonomi dalam menyelenggarakan tugas-tugasnya secara penuh. Tim Khusus partai hanya melengkapi informasi yang dibutuhkan oleh DPP Partai dalam mempertimbangkan, menetapkan, dan mengesahkan salah satu calon menjadi kandidat yang diusung dalam Pemilukada.

Dari aspek pengambilan keputusannya (sistem penentuan kandidat), kita mendapati bahwa PDI Perjuangan juga belum dapat dikatakan demokratis. Mengapa demikian? Ditinjau dari aturan yang dibuat khusus untuk menjadi pedoman dalam melakukan seleksi calon kepala daerah dan calon wakil kepala daerah serentak tahun 2018, PDI Perjuangan tidak mengatur secara eksplisit bagaimana metode yang harus ditempuh dalam menentukan kandidat, apakah melalui pemungutan suara (voting) atau melalui perolehan suara mayoritas (aklamasi). Pada peraturan tersebut, PDI Perjuangan justu menyebutkan bahwa calon yang diajukan oleh DPD dapat dianulir atau diganti oleh Ketua Umum dengan calon yang menurut pertimbangan Ketua Umum lebih baik. Hal ini dapat dibuktikan dengan salah satu pasal yang menyebutkan bahwa, dalam keadan luar biasa, Ketua Umum dapat menetapkan dan mengesahkan calon kepala daerah dan wakil kepala daerah di luar dari calon yang diajukan oleh DPD. Hal ini tentu sangat bertentangan dengan prinsip dasar demokrasi internal partai yang mengutamakan perlunya keikutsertaan (inklusifitas) seluruh anggota bahkan masyaratak luas dalam memutuskan siapa calon yang akan diusung oleh partai dalam Pemilukada.

Kandidat Hasil Seleksi, Dalam rangka memperoleh calon kandidat terbaik yang hendak diusung dan/atau didukung olen Partai di dalam Pemilukada, PDI Perjuangan telah menetapkan syarat-syarat, ketentuan dan criteria yang harus dimiliki bakal calon kandidat sebagaimana yang diatur dalam Sesuai dengan Peraturan Partai Demokrasi Indonesia Perjuangan Nomor 24 Tahun 2017 Tentang Rekrutmen dan Seleksi Calon Kepala Daerah dan Wakil Kepala Daerah Partai Demokrasi Indonesia Perjuangan.

Secara umum, PDI Perjuangan memberikan kesempatan yang seluas-luasnya menjadi calon kepala dan wakil kepala daerah bagi seluruh warga Negara Indonesia. Hal ini sesuai dengan pasal 28 ayat 1 berbunyi yang menyatakan bahwa warga Negara Indonesia yang dapat dijaring sebagai bakal calon kepala daerah dan wakil kepala daerah adalah orang yang memenuhi syarat yang ditetapkan dalam ketentuan peraturan perundang-undangan yang berlaku. Dalam upaya pembatasan calon dalam rangka perekrutan calon terbaik yang potensial, PDI Perjuangan selanjutnya menetapkan beberapa persyaratan baik bagi warga negara non PDI Perjuangan maupun warga negara yang merupakan anggota dan atau kadera partai.

Bagi warga negara yang bukan anggota partai, persyaratan khusus yang sudah ditetapkan dalam peraturan partai diatur dalam pasal 30 yang menyatakan bahwa Warga Negara Indonesia yang berasal dari luar jajaran partai yang berkeinginan mencalonkan diri atau dicalonkan sebagai bakal calon kepala daerah dan/atau wakil kepala daerah, dapat dijaring dengan criteria; a). bersedia mengikuti seluruh tahapan penjaringan dan penyaringan sebagaimana ditentukan dalam Peraturan ini; b). yang bersangkutan telah menyatakan komitmen secara tertulis kepada Dewan Pimpinan Partai pada tingkatannya untuk: 1). memperhatikan peran dan aspirasi Partai di daerahnya, 2.) bersedia membantu pengembangan dan pemberdayaan potensi partai, 3). senantiasa bersedia bekerja sama dengan jajaran struktural Partai di wilayah pemilihan yang bersangkutan; c). memiliki visi misi yang sejalan dengan ideologi dan garis perjuangan Partai; d). tidak pernah terlibat masalah narkoba secara langsung maupun 
tidak langsung; e). memiliki wawasan nasional; f). memiliki jiwa kepemimpinan yang jujur, adil, dan bebas kolusi, korupsi, dan nepotisme (KKN); g). dapat memberikan gambaran peluang untuk memenangkan Pilkada, antara lain dari dukungan masyarakat, hasil survey yang dilakukan oleh lembaga survey yang diakui dan telah ditetapkan oleh DPP Partai; dan $\mathrm{h}$ ). berkontribusi dana dalam pemenangan pilkada antara lain untuk: 1). survey internal dan/atau eksternal, 2). pelatihan guraklih dan saksi, 3.) operasional kampanye, 4). penugasan guraklih dan saksi; dan 5). operasional lain-lain yang diperlukan.

Sementara bagi warga negara yang merupakan anggota dan atau kader partai, persyaratan khusus yang sudah ditetapkan dalam peraturan partai diatur dalam pasal 28 ayat 2 yang menyatakan bahwa; a). Menyerahkan fotocopy Kartu Tanda Anggota, b). menyertakan rekomendasi dan daftar riwayat hidup yang ditandatangani pengurus partai tempat yang bersangkutan berdomisili, c). Tidak sedang terkena sanksi organisasi, d). Tidak terlibat baik langsung maupun tidak langsung dalam "Kongres PDI di Medan" dan/atau "Kongres PDI di Palu", e). Tidak menentang hasil Kongres IV Partai, f). Tidak pernah terlibat masalah narkoba secara langsung maupun tidak langsung, g). Tidak diragukan komitmen dan perjuangannya bagi partai, h). Memiliki jiwa kepemimpinan yang jujur, adil, dan bebas kolusi, korupsi, dan nepotisme (KKN), i). Memiliki ideologi, visi, dan misi yang sejalan dengan garis perjuangan Partai, j). Sanggup memberdayakan potensi Partai di daerahnya, dan turut mengembangkan serta memperjuangkan tercapainya cita-cita partai yang dituangkan dalam komitmen politik secara tertulis, k). Dapat memberikan gambaran peluang untuk memenangkan pilkada, antara masyarakat dan dukungan lainnya, dan l). Menandatangani surat pernyataan kesediaan sebagai petugas Partai yang ditandatangani di atas materai.

Selain persyaratan umum, persyaratan khusus juga ditetapkan bagi warga negara partisan yang merupakan anggota dan atau pimpinan DPRD di daerah yang bersangkutan. Persyaratan tersebut diatur dalam pasal 6 ayat 1 yang menyatakan bahwa Pimpinan DPRD Kabupaten/Kota dan Pimpinan DPRD Provinsi dilarang untuk mencalonkan atau dicalonkan sebagai calon kepala daerah dan/atau wakil kepala daerah mengingat jabatan dimaksud merupakan jabatan strategis bagi Partai guna memperjuangkan kebijakan partai menjadi kebijakan pemerintahan daerah. Pada ayat 2 dijelaskan bahwa pengecualian ketentuan ayat (1) hanya dapat dilakukan oleh DPP Partai melalui mekanisme penugasan anggota/ kader Partai. Selanjutnya pasal 3 menyatakan bahwa pimpinan DPRD kabupaten/kota dan pimpinan DPRD Provinsi yang mendapatkan penugasan dari DPP Partai sebagaimana dimaksud pada ayat (2), dijaring dan diputuskan secara langsung oleh DPP Partai dengan mempertimbangkan ideologi Partai, kepentingan Partai, soliditas Partai, popularitas dan elektabilitas calon berdasarkan hasil survey. Ketentuan lebih lanjut terkait dengan syarat khusus bagi kader partai yang menduduki jabatan strategis publik diatur dalam pasal 29 yang menyatakan bahwa anggota/kader Partai yang sedang menjabat sebagai anggota dan/atau pimpinan DPRD kabupaten/kota, DPRD Provinsi, dan/atau anggota DPR RI yang akan mendaftarkan diri sebagai bakal calon harus mendapatkan persetujuan dari DPP Partai.

Di samping persyaratan umum dan khusus calon, PDI Perjuangan juga menetapkan persyaratan yang bersifat esensial bagi setiap warga negara yang berkeinginan menjadi calon kepala dan wakil kepala daerah seperti yang diatur dalam pasal 31 yang menyatakan bahwa; a. pasangan calon kepala daerah yang berstatus sebagai kader Partai wajib menandatangani komitmen politik dan surat pernyataan sebagai petugas Partai, b. pasangan calon kepala daerah dari daerah yang perolehan kursinya di bawah $10 \%$ (sepuluh) persen dari Pemilu Legislatif terakhir, dan berstatus non kader Partai, wajib menandatangani komitmen politik, c. pasangan calon kepala daerah dari daerah yang perolehan kursinya $10 \%$ (sepuluh) persen atau lebih dari Pemilu Legislatif terakhir, dan bersatatus non kader Partai, selain wajib menandatangani komitmen politik juga wajib menandatangani surat pernyataan sebagai Petugas Partai, d. dewan Pimpinan Partai pada tingkatannya merumuskan kepentingan strategis Partai sebagai hasil penjaringan aspirasi dan kesepakatan selama penjaringan dan penyaringan bakal calon, dan dituangkan dalam komitmen politik.

Lebih jauh, pasal 32 mengamanatkan bahwa; a). komitmen politik pasangan calon 
berkaitan dengan kontribusi dana pemenangan Pemilukada sekurang-kurangnya untuk survey internal dan/atau eksternal, pelatihan guraklih dan saksi, operasional kampanye, penugasan guraklih dan saksi, dan operasionallain-lain yang diperlukan; b). Kontribusi dana pemenangan Pemilukada dimaksud dikumpulkan ke dalam rekening khusus atas nama Bendahara DPP Partai untuk dipergunakan bagi pemenangan Pemilukada di daerah yang bersangkutan; c). Penyerahan dana kontribusi dimaksud dilaksanakan paling lambat pada masa penjaringan; d). Dana kontribusi yang telah diserahkan akan dikembalikan oleh Bendahara DPP Partai apabila pasangan calon tidak ditetapkan dan disahkan oleh DPP Partai paling lambat 7 (tujuh) hari sejak penetapan dan pengesahan pasangan calon; e). Rekening khusus juga menampung kontribusi dana gotong-royong pemenangan Pemilukada yang berasal dari pengurus, petugas partai, anggota, simpatisan dan sumbangan dari pihak lain; f). Kontribusi dana pemenangan Pemilukada dimaksud hanya dipergunakan secara khusus untuk pemenangan Pemilukada di daerah yang bersangkutan, dan disampaikan penggunaannya kepada pasangan calon yang telah disahkan dan ditetapkan oleh DPP Partai dan Dewan Pimpinan Partai pada tingkatannya paling lambat 1 (satu) bulan setelah penetapan pasangan calon terpilih; g). Pasangan calon dilarang memberikan imbalan dalam bentuk apapun kepada siapapun selain kontribusi dana pemenangan Pilkada.

Dari perspektif persyaratan yang harus dipenuhi oleh kandidat, PDI Perjuangan tidak melaksanakan proses kandidasi secara demoktratis. Penjaringan dan penyaringan calon dilakukan dengan menerapkan berbagai persyaratan yang dapat membatasi atau menghalangi setiap orang untuk mengajukan diri sebagai kepala daerah dan calon wakil kepala daerah. Tidak hanya membatasi orang non partai, PDI Perjuangan juga membatasi kader yang dapat menjadi calon. Kader partai yang menduduki posisi strategis dalam jabatan publik, seperti Ketua, Wakil, dan anggota DPRD (kabupaten/kota dan atau provinsi) tidak diperkenankan untuk mengajukan diri menjadi calon kepala dan atau wakil kepala daerah, kecuali atas persetujuan atau perintah Ketua Umum. Hal ini tentu sangat bertentangan dengan pandangan Hazan \& Rahat (2010) dan
Lovenduski \& Norris (1993) yang menyatakan bahwa untuk mencapai calon yang demokratis, partai harus menghindari pembatasanpembatasan kelayakan calon kandidat. Meskipun pasal 28 ayat 1 Peraturan Partai Nomor 24 Tahun 2017 menyatakan bahwa Warga Negara Indonesia yang dapat dijaring sebagai bakal calon kepala daerah dan wakil kepala daerah adalah setiap orang yang memenuhi syarat yang ditetapkan dalam ketetentuan peraturan perundang-undangan yang berlaku. Namun pasal 28 ayat 1 ini terbantahkan oleh pasal 6 ayat 1 yang menyatakan bahwa pimpinan DPRD Kabupaten/Kota dan Pimpinan DPRD Provinsi dilarang untuk mencalonkan atau dicalonkan sebagai calon kepala daerah dan/atau wakil kepala daerah mengingat jabatan dimaksud merupakan jabatan strategis bagi Partai guna memperjuangkan kebijakan partai menjadi kebijakan pemerintahan daerah.

Namun apabila ditinjau dari aspek keterwakilan etnis di daerah penyelenggara pemilukada, penetapan calon yang dilakukan PDI Perjuangan sudah sejalan dengan Rahat, Hazan, \& Katz, (2008) dan Scarrow (2005). Penetapan Djarot Syaiful Hidayat sebagai calon gubernur, yang notabene bersuku Jawa telah mewakili masyarakat Jawa yang ada di Provinsi Sumatera Utara, dan Dr. Sihar PH. Sitorus sebagai calon wakil gubernur telah mewakili masyarkat Batak yang ada di Provinsi Sumatera Utara, dimana kedua etnik tersebut merupakan etnik mayoritas yang berdomisili di provinsi tersebut.

Pasangan calon yang diusung PDI Perjuangan dalam Pemilukada SumateraUtara tahun 2018. Calon Gubernur dan Wakil Gubernur yang ditetapkan oleh PDI Perjuangan pada Pemilukada Sumatera Utara tahun 2018 adalah Drs. Djarot Syaiful Hidayat sebagai calon gubernur dan Dr. Sihar PH. Sitorus sebagai calon wakil gubernur. Djarot Syaiful Hidayat dan Dr. Sihar PH. Sitorus adalah anggota dan kader PDI Perjuangan yang merupakan elite partai yang berkedudukan sebagai dewan pengurus pusat partai. Baik Djarot maupun Sihar merupakan kader terbaik PDI Perjuangan sebagaimana yang digambarkan pada profilnya masing masing.

\section{Dasar Pertimbangan PDI Perjuangan dalam mencalonkon Djarot dan Sihar}


Aspek Kedekatan (Loyalitas). Menurut Ketua Umum PDI Perjuangan, Megawati Soekarno Putri, pemilihan Djarot sebagai Calon Gubernur Sumatera Utara merupakan hasil diskusinya dengan Sekretaris Jenderal PDI Perjangan, Hasto Kristiyanto. Dalam diskusi itu, Megawati mengajukan beberapa pertanyaan kepada Hasto. "Saya bilang ke Hasto, 'To kenapa kita enggak lihat orang di dekat kita? Pada kesempatan itu, Hasto justru mengajukan pertanyaan kembali kepada Megawati dengan menjawab "Siapa bu?" Sang Ketua Umum pun memberikan jawaban yang sesungguhnya di luar dugaan Hasto dengan jawaban "Djarot". Hasto pun merespon jawaban Megawati dengan jawaban, "Iya ya, kok ibu brilian?" Demikian Megawati menuturkan proses pemilihan Djarot sebagai calon kandidat yang akan diusung oleh PDI Perjuangan pada Pemilukada Sumatera Utara tahun 2018 kepada salah satu wartawan Kompas. Megawati menambahkan bahwa PDI Perjuangan mengusung Djarot karena ia dinilai sebagai figur yang dikenalnya dengan baik sebagai mantan Wali Kota Blitar, mantan Wakil Gubernur DKI Jakarta, dan mantan Gubernur DKI Jakarta.

Dari pernyataan Megawati tersebut, kita dapat melihat bahwa aspek kedekatan menjadi salah satu dasar pertimbangannya dalam menunjuk Djarot sebagai calon gubernur. Kedekatan dalam hal ini dapat diartikan sebagai suatu hubungan yang erat antara Megawati sebagai Ketua Umum dengan Djarot sebagai salah satu kader partai yang telah memiliki reputasi yang tinggi di jajaran elit partai, baik dalam jabatan publik maupun jabatan politik. Keeratan hubungan tersebut juga dipengaruhi oleh posisi Djarot yang menjabat sebagai salah satu Ketua Dewan Pengurus Pusat PDI Perjuangan. Tentu itu merupakan sautu jaminan bagi Ketua Umum untuk meyakinkan dirinya untuk memilih Djarot sebagai figur yang tepat untuk dicalonkan sebagai kandidat gubernur Sumatera Utara.

Aspek Kapasitas dan Kapabilitas Calon. Menurut Megawati, Provinsi Sumatera Utara merupakan salah satu provinsi strategis yang membutuhkan pemimpin yang berkompeten dalam pemberantasan korupsi. Ia mengklaim bahwa Djarot memiliki kapasitas dan kompetensi dalam memberantas korupsi yang pernah membelit beberapa kepala daerah di Provinsi Sumatera Utara, termasuk Gubernur Sumatera Utara itu sendiri. Megawati menyatakan bahwa pemberantasan korupsi merupakan salah satu pertimbangan yang mendasarinya dalam menetapkan Djarot sebagai bakal calon gubernur untuk Sumatera Utara. (4/1/2018).

Djarot merupakan tokoh muda yang penuh dengan pengalaman dalam memimpin daerah. Mantan Gubernur DKI Jakarta tersebut diyakini oleh Megawati mampu membuat perubahan signifikan di provinsi yang dianggapnya sebagai daerah strategis dalam pertumbuhan perekonomian nasional. Djarot juga memiliki rekam jejak yang bersih selama menduduki jabatan publik dan Dia akan menjadi antitesa bagi gubernur Sumatera Utara sebelumnya yang sering tersandung dengan persoalan-persoalan hukum, khususnya masalah korupsi. Menurut Megawati Djarot adalah orang yang bagus dan sangat serius sehingga Dia akan mampu membawa perubahan bagi Provinsi Sumatera Utara.

Lebih jauh Megawati menjelaskan bahwa dasar pertimbangannya memilih Djarot untuk maju di Pemilukada Sumatera Utara adalah kemampuan Djarot untuk memajukan perekonomian masyarakat Sumatera Utara sebagai pusat perekonomian nasional. Dengan latar belakang dan jejak rekam Djarot yang dinilai memiliki kompetensi dan kapabilitas yang mumpuni, masyarakat Sumut dapat menerima Djarot sebagai Gubernur. "Mudahmudahan rakyat Sumut bisa lihat. Tolonglah terima Pak Djrot, karena kan di sana banyak juga (orang) Jawanya, . Demikian penjelasan Megawati tetang penghunjukan Djarot sebagai Calon Gubernur Sumatera Utara dalam perhelatan Pemilukada Provinsi Sumatera Utara tahun 2018.

Aspek Kesejarahan Partai. Menurut Sekretaris Jenderal PDI Perjuangan, Hasto Kristiyanto, Sumatera Utara memiliki sejarah penting bagi PDI Perjuangan. Hal itu berkaitan dengan perjalanan Soekarno dalam usahanya memerdekakan Indonesia. Hasto menyatakan bahwa sejarah tersebut berhubungan dengan perjuangan pahit Bung Karno yang pernah diasingkan oleh Belanda di Brastagi dan Parapat. Oleh karena itu, Provinsi Sumatera Utara harus dipimpin oleh kader PDI Perjuangan. Disamping keterkaitannya dengan Bung Karno, menurut Hasto, Provinsi Sumatera Utara juga merupakan daerah lumbung suara 
PDI Perjuangan, baik pada perhelatan Pemilu maupun Pemilukada sebelumnya. Dari perspektif kesejarahan dan pencapaian PDI Perjuangan pada Pemilukada serentak tahun sebelumnya, Hasto menilai Sumatera Utara dapat menjadi pilar bagi PDI Perjuangan. Oleh karena itu, menurut Hasto, Djarot adalah calon yang paling tepat untuk disung pada Pemilukada Provinsi Sumatera Utara tahun 2018.

Pengalaman Calon. Salah satu Ketua DPP, Hendrawan Supratikno, juga memyampaikan pandangannya terkait dengan pencalonan Djarot sebagai Calon Gubernur Sumatera Utara pada Pemilukada 2018. Menurutnya, ada beberapa pertimbangan yang memunculkan nama mantan Wali Kota Blitar, Jawa Timur, tersebut sebagai calon kandidat yakni pengalaman Djarot sebagai Wali Kota Blitar, Wakil Gubernur, dan Gubernur DKI Jakarta.

Dengan alasan tersebut, PDI Perjuangan menilai bahwa Sumatera Utara harus dipimpin oleh figur yang sudah berpengalaman di bidangnya. Sebagai provinsi yang gubernurnya sering tersandung kasus hukum maka perlu menghadirkan seorang pejabat yang bersih dan transparan. Hendrawan menilai bahwa Sumatera Utara sudah berkali-kali tersandung dengan masalah birokrasi dan korupsi. Sebagai salah satu provinsi yang sangat penting bagi partai, maka perlu mengutus Djarot untuk melakukan perubahan mendasar di Sumatera Utara.

Selain Hendrawan, Ketua DPP PDI Perjuangan lainnya, Andreas Pareira, juga menyampaikan pandangannya terkait pencalonan Djarot sebagai Calon Gubernur Sumatera Utara. Menurutnya, Djarot diusung karena partainya mendapat usulan dari masyarakat setempat. Ia mengklaim bahwa warga Sumatera Utara menginginkan pemimpin yang setia menghabiskan masa jabatannya sebagai gubernur. "Selama ini, di Sumut, hampir semua Gubernur tidak bisa menyelesaikan tugasnya sampai tuntas. Terjerat masalah korupsi, maupun persoalan transparansi. Djarot, disebut pemimpin yang mempunyai kapabilitas dalam mengelola pemerintahan".

Andreas meyakini, Djarot yang sudah berpengalaman menjadi kepala daerah dapat menjalankan tugas dengan baik sampai masa akhir jabatannya. Dengan modal pengalaman sebagai Wali Kota Blitar sebanyak 2 periode, Wakil Gubernur, dan Gubernur DKI Jakarta maka masyarakat Sumatera Utara akan merespon baik pencalonannya sebagai Calon Gubernur. Meski demikian, Andreas menampik anggapan publik yang menyatakan bahwa PDIP kekurangan kader terbaik untuk dicalonkan dalam sejumlah kontestasi Pemilukada serentak 2018. Sebagai kader partai, setiap anggota harus bersedia ditempatkan di seluruh wilayah Indonesia.

Rekam Jejak Calon. Menurut politisi muda PDI Perjuangan, Maruarar Sirait, Djarot Syaiful Hidayat telah memenuhi berbagai aspek untuk diusung menjadi calon Gubernur Sumatera Utara. "Pak Djarot kan sudah terbukti punya rekam jejak yang baik, pernah jadi wali kota di Blitar, kemudian jadi Wakil Gubernurnya Pak Ahok, lalu jadi Gubernur DKI Jakarta." Selain pengalaman yang mumpuni dan melimpah sebagai kepala daerah, Djarot juga dikenal sebagai figur yang bersih dari kasus hukum maupun kasus korupsi. Aspek-aspek inilah yang menjadi nilai tambah Djarot sebagai calon gubernur potensial yang harus dimenangkan partai. Sebab menurut Maruar, pemerintahan Provinsi Sumatera Utara perlu memiliki kepala daerah yang bersih dari kasus korupsi dan memiliki good will dan political will dalam upaya pembersihan praktik-praktik korupsi dari seluruh aspek pelayanan publik di pemerintah daerah Sumatera Utara.

Senada dengan Maruar Sirati, Sekretaris Jenderal PDI Perjuangan Daerah Sumatera Utara, Soetarto menyatakan bahwa pengalaman sebagai Wali Kota Blitar sebanyak 2 periode, Wakil Gubernur DKI Jakarta, dan Gubernur DKI Jakarta yang sudah teruji dan terbukti menjadi dasar pertimbangan PDI Perjuangan untuk mengusung Djarot sebagai Calon Gubernur dalam Pemilukada Provinsi Sumatera Utara tahun 2018. "Pengalaman beliau tentu saja sudah teruji dan terbukti. Bagi PDI Perjuangan, karena konstelasi dan kondisi Sumatra Utara yang dipimpin oleh dua gubernur sebelumnya yang tersangkut dengan masalah-masalah hukum, maka kita butuh pemimpin yang memang bersih".

Soetarto menegaskan bahwa isu putra daerah dalam Pemilukada Sumatera Utara tidaklah relevan. Menurutnya, masyarakat harus memandangnya dari perspektif negara kesatuan Republik Indonesia. Dengan perspektif itu maka pendikotomian antara 
putra daerah dan bukan putra daerah akan terbantahkan dengan sendirinya. Dengan konsepsi Negara Kesatuan Repubik Indonesia maka setiap warga negara Indonesia memiliki hak dan kesempatan yang sama untuk mengambil peran dalam penyelenggaraan negara di seluruh wilayah Republik Indonesia.

Aspek Popularitas Calon. Selain memiliki rekam jejak yang bersih dan kemampuan yang mumpuni, Soetarto menambahkan bahwa, masyarakat Sumatra Utara sudah mengenal Djarot dengan baik. Hal itu dibuktikannya saat ia mendampingi Djarot dalam kunjungannya ke beberapa wilayah di Sumatera Utara. "Di Siantar contohnya, saat Djarot tiba banyak warga masyarakat yang bersorak sorai menyambutnya sambil meminta untuk berswafoto. Sama hal nya dengan di Kota Parapat, sambutan masyarakat sangat luar biasa. Bahkan sampai ada warga masyarakat yang nepuk-nepuk wajah Djarot. Menurut Soetarto hal itu menunjukkan suasana kebatinan yang sangat luar biasa yang ditunjukkan oleh masyarakat terhadap Djarot. Respon tersebut mengindikasikan satu harapan yang sangat besar dari masyarakat kepada sosok Djarot Saiful Hidayat yang dipandang transparan dan bersih dalam menjalankan roda pemerintahan.

Senada dengan Soetarto, Wakil Sekretaris DPD PDI Perjuangan Sumatera Utara, Ahmad Bima Nusa juga menyatakan bahwa Djarot merupakan sosok yang sudah sangat populer di kancah politik Indonesia. Kepopuleran Djarot dimulai sejak Ia dipilih oleh DPP PDI Perjuangan untuk mendamping Ahok dalam melanjtkan kepemimpinan Jokowi-Ahok di DKI Jakarta serta pemilihan gubernur DKI Jakarta pada tahun 2017. Berkaitan dengan hal tersebut, Ahmad Bima Nusa berkeyakinan bahwa Djarot akan mampu memenangkan Pemilukada Sumatera Utara pada tahun 2018.

Dasar Pertimbangan Sihar Sebagai Calon Wakil Gubernur, adalah Kedekatan. Di samping kesulitan dalam memilih calon gubernur, Ketua Umum PDI Perjuangan juga sempat mengalami hal yang sama dalam memilih calon pendamping Djarot sebagai calon wakil gubernur untuk menghadapi Pemilukada Sumatara Utara tahun 2018. Namun pada akhirnya, Megawati memilih staf ahli Menteri Koordinator Pemberdayaan Manusia, yakni Sihar PH Sitorus untuk mendampingi Djarot sebagai calon wakil gubernur Sumatera Utara. Megawati mengaku bahwa Dia dan Menteri Koordinator Pemberdayaan Manusia, yang juga merupakan Putri kandungnya, Puan Maharani sempat memiliki perbedaan pendapat tentang pemilihan Sihar PH Sitorus sebagai calon wakil gubernur untuk mendapingi Djarot di Pemilukada Sumatera Utara.

Di awal penunjukan Sihar sebagai calon wakil gubernur, Puan Maharani tidak setuju dengan Ketua Umum PDI Perjuangan pada Pemilukada Sumatera Utara. Namun demikian, Megawati tetap bersikukuh pada pendiriannya untuk tetap memilih Sihar sebagai pasangan terbaik untuk Djarot dalam memenangi Pemilihan Gubernur Sumatera Utara tahun 2018. Megawati melanjutkan, meskipun Dia mendapat berbagai tawaran calon dari berbagai marga yang ada di Sumatera Utara untuk dipilih, namun Ia lebih mengedepankan sosok atau calon yang dapat memimpin Sumatera Utara dengan baik. Ketua Umum PDIP Megawati Soekarnoputri, akhirnya menunjuk Sihar Sitorus, sebagai calon wakil gubernur mendampingi Djarot Saiful Hidayat di Pilgub Sumut tahun 2018. Megawati mengatakan, dirinya telah mempertimbangkan dan mendengar semua masukan dari jajarannya terkait keputusan tersebut. "Dia ini anaknya Pak DL Sitorus. Salah satu Jurkam, lalu jadi Tim Ahli Ekonomi Jokowi JK. Dia ini beda sama bapaknya, saya kan kenal sama DL. Mungkin dia datang dari sebelah sananya. Ini pasangan Sumut yang perlu kita fight," kata Megawati Soekarnoputri di Kantor DPP PDIP, Lenteng Agung, Jakarta Selatan, Minggu (7/1/2018).

Aspek Kapasitas dan Kapabilitas Calon. Berbeda dengan Djarot yang berlatarbelakang akademisi dan politisi dengan kemampuan yang sudah teruji di bidang penyelenggaraan pemerintahan, Sihar memiliki kecakapan dalam berbagai bidang, terutama dalam pengembangan bisnis, pemberdayaan masyarakat, serta pengembangan olah raga. Jika Djarot memiliki keahlian dalam bidang pemerintahan dan politik, maka Sihar lebih berbakat dalam bidang pengembangan ekonomi dan pemberdayaan masyarakat, khususnya masyarakat perkebunan. Hal ini lah yang meyakinkan Megawati untuk memilih Sihar sebagai padanan yang pas dan seimbang untuk membangun Sumatera Utara yang maju 
dan sejahtera sesuai dengan cita-cita PDI Perjuangan.

Rekam Jejak (Reputasi) Calon. Sebagai figur yang memiliki latar belakang pendidikan yang hebat, pengalaman dalam manajemen bisnis dan perusahaan yang mempuni, serta kepedulian Sihar terhadap masyarkat dan olah raga serta pengalamannya dalam mendampingi Menteri Koordinator Pembangunan Manusia dan Kebudayaan Republik Indonesia menjadi dasar pertimbangan Ketua Umum PDI Perjangan dalam menugaskan Sihar untuk mendapingi Djarot menghadapi Pemilukada Provinsi Sumatera Utara tahun 2018.

\section{SIMPULAN}

PDI Perjuangan menerapkan suatu bentuk demokrasi internal partai dengan pola yang terpimpin dimana Ketua Umum memiliki kewenangan istimewa dalam menentukan bentuk dan prosedur tata laksana demokrasi internal itu sendiri yang dijamin oleh Piagam Partai, Anggaran Dasar Partai, dan Anggaran Rumah Tangga Partai; PDI Perjuangan menerapkan suatu bentuk demokrasi internal yang berbeda dengan prinsip-prinsip demokrasi liberal, yang salah satu prinsip fundamentalnya adalah keterbukaan dan keikutsertaan seluruh elemen partai dalam setiap dinamika politik partai; Desentralisasi politik politik tidak diselenggarakan sebagai upaya untuk mencegah timbulnya faksi-faksi yang dapat menyebabkan terjadinya perpecahan-perpecahan dalam tubuh partai, baik antar badan partai maupun antar tingkatan dewan pengurus partai; Rekrutmen calon kepala daerah dan atau wakil kepala daerah tidak diselenggarakan secara demokratis sesuai dengan prinsip demokrasi liberal, dimana pengambilan keputusan dalam pencalonan kandidat berada pada Ketua Umum Partai. Penetapan Djarot-Sihar sebagai pasangan calon gubernur dan wakil gubernur Provinsi Sumatara Utara pada Pemilukada tahun 2018 didasarkan pada pertimbangan strategis partai sesuai dengan kalkulasi politik Ketua Umum dan jajaran elite partai.

\section{DAFTAR PUSTAKA}

Amal, I., (1996), Teori-teori Mukhtahir Partai Politik, Amin, M. (2017). Model Practice Of Drafting The Code Of Ethics Of Politicians And Political Parties In Indonesia.
Budi, A. (2013). Membongkar Veto Player dalam Politik Kepartaian Indonesia Menuju Pemilu 2014. Jurnal Ilmu Sosial dan Ilmu Politik, 17(1), 51-66.

Castles, L., \& Feith, H. (Eds.). (1970). Indonesian Political Thinking, 1945-1965. Cornell University Press.

Cross, W. P., \& Katz, R. S. (Eds.). (2013). The challenges of intra-party democracy. OUP Oxford.

Cular, G. (2005). „Organisational Development of Parties and Internal Party Democracy in Croatia”, in „Organizational Structures and Internal Party Democracy in South Eastern Europe". Friedrich Ebert Stiftung.

Duverger, M. (1964). Political Parties: A Behavioural Analysis.

Farrell, D. M., LeDuc, L., Niemi, R., \& Norris, P. (1996). Campaign strategies and tactics. In Comparing democracies: Elections and voting in global perspective. Sage Publications Ltd.

Firmanzah, M. P. (2007). Antara Pemahaman dan Realitas. Jakarta: Yayasan Obor Indonesia.

Gunther, R., \& Diamond, L. (2003). Species of political parties: A new typology. Party politics, 9(2), 167-199.

Haris, S. (2014). Partai, pemilu, dan parlemen era reformasi. Yayasan Pustaka Obor Indonesia.

Haris, S. (Ed.). (2005). Pemilu langsung di tengah oligarki partai: proses nominasi dan seleksi calon legislatif Pemilu 2004. Gramedia Pustaka Utama.

Hazan, R. Y., \& Rahat, G. (2010). Democracy within parties: Candidate selection methods and their political consequences. OUP Oxford.

Husodo, A.T., (2009), Gunung Es Korupsi di Parlemen: Jangan Bunuh KPK, Jakarta: Gramedia,

Kabasakal, M. (2014). Factors influencing intraparty democracy and membership rights: The case of Turkey. Party Politics, 20(5), 700-711.

Katz, R. S. (2005). Why are there so many (or so few) electoral reforms. The politics of electoral systems, 57-76.

Lipset, S. M. (1983). Political Man, The Social Bases of Politics. 2nd expanded Edition.

Maor, M. (2005). Political parties and party systems: comparative approaches and the British experience. Routledge.

Meleshevich, A. (2007). Party systems in post-Soviet countries: a comparative study of political institutionalization in the Baltic States, Russia, and Ukraine. Springer.

Michels, R., Lipset, S. M., Paul, E., \& Paul, C. (2017). Political parties: A sociological study of the oligarchical tendencies of modern democracy. Routledge 
Moleong, L.J., (2010), Metodologi Penelitian Kualitatif.

Nge, H. J. (2018). Oligarki Partai Politik dalam Rekrutmen Calon Kepala Daerah. Jurnal Academia Praja, 1(01), 59-84.

Norris, P. (2004). Building Political Parties: Reforming legal regulations and internal rules. Report commisioned international IDEA.

Nurazizah, T., \& Dewi, D. (2021). Perjalanan Demokrasi di Indonesia serta Pendidikan Kewarganegaraan sebagai Pendidikan Demokrasi yang Berkarakter. Journal of Education, Humaniora and Social Sciences (JEHSS), 4(1), 257-263. doi:https://doi.org/10.34007/iehss.v4i1.646

Nurdin, A. (2021). Politik Uang dan Prospek Konsolidasi Demokrasi Indonesia. Journal of Education, Humaniora and Social Sciences (JEHSS), $4(1)$, 190-196. doi:https://doi.org/10.34007/jehss.v4i1.609

Pamungkas, S., \& Parlindungan, U. (2011). Partai politik: teori dan praktik di Indonesia. Institute for Democracy and Welfarism.

Pasquino, G. (2005). The political science of Giovanni Sartori. European Political Science, 4(1), 33-41.

Pennings, P., \& Hazan, R. Y. (2001). Democratizing candidate selection: causes and consequences. Party Politics, 7(3), 267-275.

Putra Alamsyah, M., Nasution, M., \& Harahap, R. (2021). Analisis Sosialisasi Politik Relawan Demokrasi Basis Warga Internet Kota Medan Pemilihan Umum Tahun 2019. PERSPEKTIF, 10(1), 65-75. doi:https://doi.org/10.31289/perspektif.v1 0 i1.3923

Rahat, G., Hazan, R. Y., \& Katz, R. S. (2008). Democracy and political parties: On the uneasy relationships between participation, competition and representation. Party politics, 14(6), 663-683.

Ramadani. Nasution, I. \& Tarigan, U. (2017). Analisis Pemilihan Kepala Desa Serentak terhadap Demokrasi Lokal di Desa Tanjung Kabupaten Aceh Tamiang. PERSPEKTIF, 7 (2): 40-45

Richard, S. K. W. J., \& Crotty, W. (2006). Handbook of Party Politics.

Salang, S. (2007, October). Potret Partai Politik di Indonesia, Asesmen Terhadap Kelembagaan, Kiprah, dan Sistem Kepartaian. In Jakarta: Forum Politisi-Friedrich Naumann Stiftung.

Sandri, G., \& Amjahad, A. (2015). Party membership and Intra-party democracy: How do members react to organizational change within political parties? The case of Belgium. Partecipazione e conflitto, 8(1), 190-214.
Sartori, G. (2015). 5. European Political Parties: The Case of Polarized Pluralism. In Political Parties and Political Development.(SPD6) (pp. 137-176). Princeton University Press.

Scarrow, S. E. (2005). Political parties and democracy in theoretical and practical perspectives: Implementing intra-party democracy. National Democratic institute for international Affairs.

Schattschneider, E. E. (1942). Party Government. New York: Farrar and Rinehart. Inc. SchattschneiderParty Government1942.

Siavelis, P. M., \& Morgenstern, S. (2008). Candidate recruitment and selection in Latin America: a framework for analysis. Latin American Politics and Society, 50(4), 27-58.

Sinaga, R. S. (2018). Demokratisasi Kelembagaan Partai Politik Di Indonesia Melalui Manajemen Partai Politik Modern: Tinjauan Teoritis Dan Regulasi.

Sugiyono, (2008). Metode Penelitian Kuantitatif Kualitatif dan R\&D.CV. Alfabeta, Bandung.Surbakti, Ramlan: Memahami Ilmu Politik, Jakarta: Grasindo, 1992.

Suharyanto, A. (2017). Pemahaman Siswa Tentang Konsep Demokrasi Dalam Pendidikan Kewarganegaraan, dalam Prosiding Seminar Nasional Tahunan Fakultas Ilmu Sosial Universitas Negeri Medan Tahun 2017 Vol. 1 No. 1 2017, Hal. 530-534

Van Biezen, I., \& Piccio, D. R. (2013). Shaping intraparty democracy: On the legal regulation of internal party organizations. The challenges of intra-party democracy, 27-48.

Von dem Berge, B., Poguntke, T., Obert, P., \& Tipei, D. (2013). Measuring intra-party democracy. Heidelberg: Springer.

Von dem Berge, B., Poguntke, T., Obert, P., \& Tipei, D. (2013). Measuring intra-party democracy. Heidelberg: Springer.

Wibowo, P.A, (2013), Mahalnya Demokrasi Memudarnya Ideologi: Potret Komunikasi Politik Legislator-Konstituen, Jakarta: Kompas.

Wicaksono, B. (2021). Parodi Politik dalam Demokrasi Digital Studi Kasus: Akun Instagram Nurhadi-Aldo. PERSPEKTIF, 10(1), 36-46.

doi:https://doi.org/10.31289/perspektif.v1 0 i1.3996

Witianti, S. (2019). Peran Ketua Umum Partai Politik Dalam Pencalonan Kepala Daerahpada Pemilihan Kepala Daerah Serentak Di Indonesia. JWP (Jurnal Wacana Politik), 4(1).

https://www.cnnindonesia.com/Pemilukadaserent ak/nasional/20180208184421-32-274895/ indonesia dinilai-lupa-menata-partai-politikselama-reformasi? 
Junedi Lumban Gaol, Muryanto Amin \& Heri Kusmanto. Demokratisasi Dan Desentralisasi Partai Demokrasi Indonesia Perjuangan Dalam Pemilukada Provinsi Sumatera Utara Tahun 2018.

https://www.cnnindonesia.com/Pemilukadaserent ak/nasional/20180208184421-32-

274895/indonesia-dinilai-lupa-menatapartai-politik-selama-reformasi?

https://nasional.kompas.com/read/2018/01/04/2 1201911/cerita-megawati-di-balikterpilihnya-djarot-jadi-calon-gubernursumut. Artikel ini tayang di Kompas.com dengan judul "Cerita Megawati di Balik Terpilihnya Djarot Jadi Calon Gubernur Sumut", Kompas.com-04/01/2018, 21:20 WIB

https://www.rekamjejak.net/database/read/235/ drs-djarot-saiful-hidajat.html

https://www.viva.co.id/siapa/read/124-djarotsaiful-hidayat

Http://www.kabarindonesia.com/berita.php?pil=2 $1 \& \mathrm{jd}=$ Dr+Sihar + Sitorus + Calon + Wagub + Sum ut+pada+Pilkada+2018\&dn=201801181146 59

Artikel ini telah tayang di Kompas.com dengan judul "PDI-P Usung Djarot Saiful Hidayat sebagai
Calon Gubernur di Pemilukada Sumut". https://nasional.kompas.com/read/2018/0 1/04/15274101/pdi-p-usung-djarot-saifulhidayat-sebagai-calon-gubernur-diPemilukada-sumut.

https://sumut.inews.id/berita/megawati-yakindjarot-bisa-majukan-daerah-sumut/29461

https://koransulindo.com/sumatera-utara-punyasejarah-tersendiri-bagi-pdi-perjuangan/

https://www.liputan6.com/news/read/3214890/ megawati-pilih-diarot-saiful-hidavatsebagai-cagub-sumut

https://www.suara.com/news/2018/01/06/1315 59/ini-alasan-pdip-pilih-djarot-jadi-jago-diPemilukada-sumut

https://nasional.kompas.com/read/2018/01/02/2 0351501/bersih-djarot-dinilai-penuhikriteria-calon-gubernur-sumut.

https://www.bbc.com/indonesia/indonesia42493569. 